\title{
Relationship between oxygen consumption and neuronal activity in a defined neural circuit
}

\author{
Suzan Özugur ${ }^{1,2}$, Lars Kunz $^{1}$ (D) and Hans Straka ${ }^{1 *}$ (D)
}

\begin{abstract}
Background: Neuronal computations related to sensory and motor activity along with the maintenance of spike discharge, synaptic transmission, and associated housekeeping are energetically demanding. The most efficient metabolic process to provide large amounts of energy equivalents is oxidative phosphorylation and thus dependent on $\mathrm{O}_{2}$ consumption. Therefore, $\mathrm{O}_{2}$ levels in the brain are a critical parameter that influences neuronal function. Measurements of $\mathrm{O}_{2}$ consumption have been used to estimate the cost of neuronal activity; however, exploring these metabolic relationships in vivo and under defined experimental conditions has been limited by technical challenges.
\end{abstract}

Results: We used isolated preparations of Xenopus laevis tadpoles to perform a quantitative analysis of $\mathrm{O}_{2}$ levels in the brain under in vivo-like conditions. We measured $\mathrm{O}_{2}$ concentrations in the hindbrain in relation to the spike discharge of the superior oblique eye muscle-innervating trochlear nerve as proxy for central nervous activity. In airsaturated bath Ringer solution, $\mathrm{O}_{2}$ levels in the fourth ventricle and adjacent, functionally intact hindbrain were close to zero. Inhibition of mitochondrial activity with potassium cyanide or fixation of the tissue with ethanol raised the ventricular $\mathrm{O}_{2}$ concentration to bath levels, indicating that the brain tissue consumed the available $\mathrm{O}_{2}$. Gradually increasing oxygenation of the Ringer solution caused a concurrent increase of ventricular $\mathrm{O}_{2}$ concentrations. Blocking spike discharge with the local anesthetics tricaine methanesulfonate diminished the $\mathrm{O}_{2}$ consumption by $\sim 50 \%$, illustrating the substantial $\mathrm{O}_{2}$ amount related to neuronal activity. In contrast, episodes of spontaneous trochlear nerve spike bursts were accompanied by transient increases of the $\mathrm{O}_{2}$ consumption with parameters that correlated with burst magnitude and duration.

Conclusions: Controlled experimental manipulations of both the $\mathrm{O}_{2}$ level as well as the neuronal activity under in vivo-like conditions allowed to quantitatively relate spike discharge magnitudes in a particular neuronal circuitry with the $\mathrm{O}_{2}$ consumption in this area. Moreover, the possibility to distinctly manipulate various functional parameters will yield more insight in the coupling between metabolic and neuronal activity. Thus, apart from providing quantitative empiric evidence for the link between physiologically relevant spontaneous spike discharge in the brain and $\mathrm{O}_{2}$-dependent metabolism, isolated amphibian preparations are promising model systems to further dissociate the $\mathrm{O}_{2}$ dynamics in relation to neuronal computations.

Keywords: Xenopus laevis, Oxidative phosphorylation, Ventricle, Extraocular motoneurons

\footnotetext{
* Correspondence: straka@Imu.de

'Department Biology II, Ludwig-Maximilians-University Munich, Großhaderner Str. 2, 82152 Planegg, Germany

Full list of author information is available at the end of the article
} which permits use, sharing, adaptation, distribution and reproduction in any medium or format, as long as you give appropriate credit to the original author(s) and the source, provide a link to the Creative Commons licence, and indicate if changes were made. The images or other third party material in this article are included in the article's Creative Commons licence, unless indicated otherwise in a credit line to the material. If material is not included in the article's Creative Commons licence and your intended use is not permitted by statutory regulation or exceeds the permitted use, you will need to obtain permission directly from the copyright holder. To view a copy of this licence, visit http://creativecommons.org/licenses/by/4.0/ The Creative Commons Public Domain Dedication waiver (http://creativecommons.org/publicdomain/zero/1.0/) applies to the data made available in this article, unless otherwise stated in a credit line to the data. 


\section{Background}

The brain requires a disproportionately large amount of energy compared to its fraction of body mass [1]. This large amount of energy ensures maintenance of the functionality of the cellular components such as neurons and glial cells [2] and is indicated by the considerable $\mathrm{O}_{2}$ consumption by this organ [3]. The close correlation between energy demand and $\mathrm{O}_{2}$ supply derives from the fact that the generation of adenosine triphosphate (ATP) as most important energy equivalent occurs mainly via oxidative phosphorylation $[4,5]$. This highly productive metabolic process takes place in mitochondria and requires considerable amounts of $\mathrm{O}_{2}$ [4]. In the brain, this aerobic generation of energy is assigned mostly, even though not exclusively to neurons. In contrast, glial cells largely depend on anaerobic mechanisms, producing lactate, which also fuels oxidative phosphorylation in neurons $[6,7]$. Thus, $\mathrm{O}_{2}$ turnover has been used in the past in a number of experimental and theoretical studies to estimate the cost of neuronal activity from single-cell conductance to network computations (e.g., [8-10]). However, only few studies have provided reliable estimates of the $\mathrm{O}_{2}$ consumption under defined experimental conditions (e.g., neuronal activity patterns) because of the generally challenging technical requirement of $\mathrm{O}_{2}$ measurements and the difficult relation between consumption and spike firing [5, 8-12].

The ATP and $\mathrm{O}_{2}$ demand for specific neuronal functions such as action potential generation, maintenance of resting membrane potential, or integration of inhibitory and excitatory synaptic inputs $[2,13,14]$ has often been determined only indirectly by measuring metabolites such as nicotinamide adenine dinucleotide (NADH) and flavin adenine dinucleotide (FAD) mostly in mammalian brain slice preparations or cell cultures [15-21]. A number of mainly theoretical considerations have demonstrated that particular neuronal processing features require a certain amount of energy in form of ATP and $\mathrm{O}_{2}[2,22-25]$. Some of these calculations have been confirmed by rather rare empiric experimental examples, mostly in slice preparations that were able to demonstrate a direct link between, e.g., neuronal spike discharge and $\mathrm{O}_{2}$ consumption $[8-10,12,26]$, which are difficult to achieve in vivo in intact animals. This limitation is largely due to the massively invasive way of directly recording $\mathrm{O}_{2}$ concentrations under defined conditions using $\mathrm{O}_{2}$ electrodes along with the concurrent neuronal activity. This at least in part explains the current lack of larger sets of experimental data that allow a direct correlation of $\mathrm{O}_{2}$ levels and neuronal activity.

Isolated in vitro whole brains or entire heads of amphibians (frogs: [27]; Axolotl: [28]) or reptilian species (snakes: [29]; turtles: [30]) represent excellent alternatives to study more complex neuronal computations related to in vivo-like behavior. After isolation, these preparations are usually maintained in airsaturated bath solutions. Remarkably, such isolated preparations can be maintained functionally intact for several days and employed for extended periods of recordings of spike discharge (e.g., $[29,31]$ ) or calcium transients (e.g., $[28,32])$ during natural or electrical activation of sensory inputs. Despite the established use for systemic neuroscientific studies, only little is known about the requirements for the consumption of $\mathrm{O}_{2}$ by the tissue in such preparations or the relation between neuronal activity and the $\mathrm{O}_{2}$ level in the brain.

Here, we used isolated preparations of Xenopus laevis tadpoles to monitor the $\mathrm{O}_{2}$ level in the IV ${ }^{\text {th }}$ ventricle and adjacent hindbrain. In air-saturated bath Ringer solution, the $\mathrm{O}_{2}$ concentration in the ventricular compartment was negligible, but increased to bath $\mathrm{O}_{2}$ levels following metabolic inactivation of the brain with potassium cyanide $(\mathrm{KCN})$ or after ethanol $(\mathrm{EtOH})$ fixation. The suggestive consumption of the entirety of available $\mathrm{O}_{2}$ under control conditions was confirmed in experiments in which the spike discharge was blocked by the local anesthetic tricaine methanesulfonate (MS-222). A correlation between neuronal discharge and $\mathrm{O}_{2}$ level was further elucidated during spontaneous spike bursts in a specific motor nerve, indicating causality between discharge magnitude and $\mathrm{O}_{2}$ consumption. Preliminary data were previously published in abstract form [33].

\section{Results}

\section{Oxygen concentration profile}

A potentially differential $\mathrm{O}_{2}$ distribution and gradient within and around the isolated preparation was tested by constructing a depth profile of the $\mathrm{O}_{2}$ concentration (Fig. $1 \mathrm{a}_{2}$, b-d). Following placement of the isolated preparation in the center of the recording chamber, one $\mathrm{O}_{2}$ electrode was positioned at a distance of $5 \mathrm{~mm}$ lateral to the preparation in a depth below the Ringer surface that matched the floor of the $\mathrm{IV}^{\text {th }}$ ventricle. Under control conditions with air-saturated Ringer solution (292 \pm $4 \mu \mathrm{mol} / \mathrm{l}$, mean \pm SEM; $N=31$ preparations), the second electrode was used to establish a step-wise dorso-ventral and medio-lateral profile of the $\mathrm{O}_{2}$ concentration within and around the tissue of the isolated preparation at the level of the hindbrain (see the "Methods" section). Measurements of the $\mathrm{O}_{2}$ level within the recording grid (white dots in Fig. 1b) and construction of a concentration map by extra- and interpolation revealed a differential distribution of the $\mathrm{O}_{2}$ levels around the tissue (colorcoded map in Fig. 1b). While most of the Ringer solution above the preparation remained air-saturated (red in Fig. 1b), the region in proximity of the tissue $(<1.0$ $\mathrm{mm}$ ) became gradually more $\mathrm{O}_{2}$-depleted (violet in 


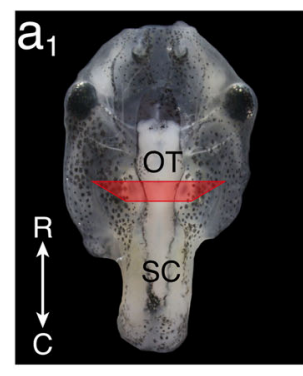

$a_{2}$

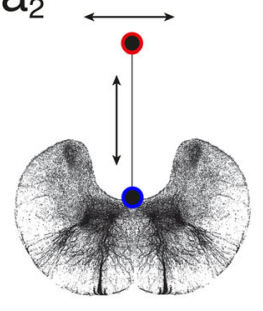

C

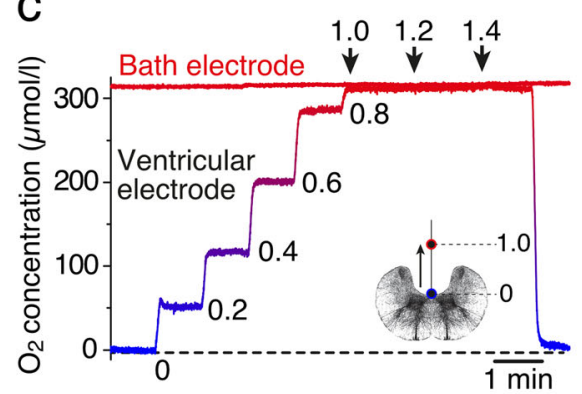

e

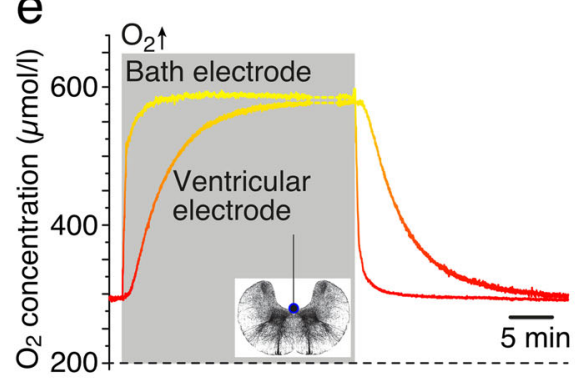

g

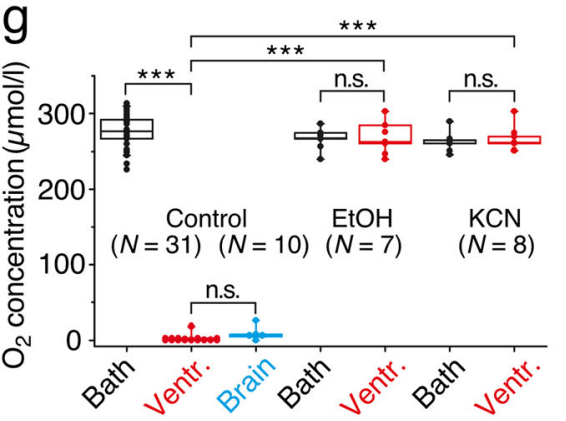

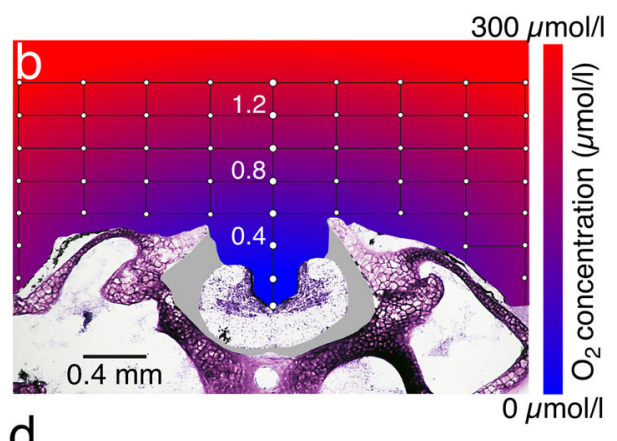

d

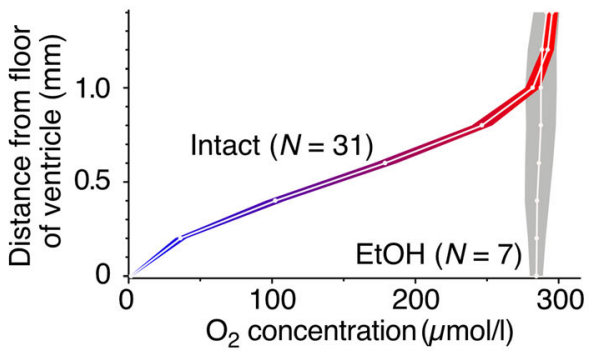

$f$

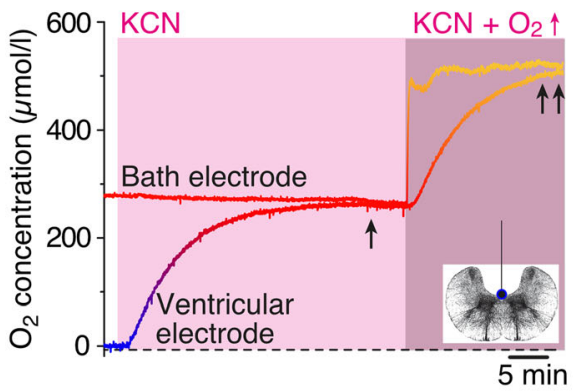

h

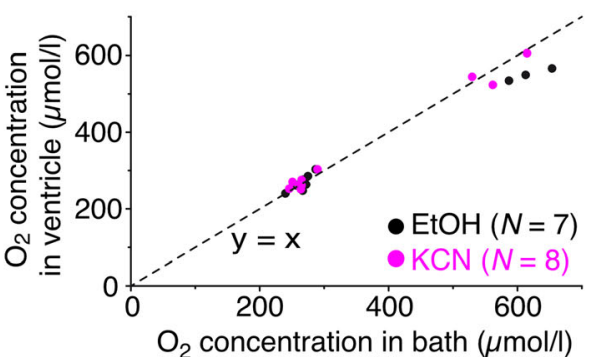

Fig. 1. Measurements of $\mathrm{O}_{2}$ levels in isolated preparations. $\mathbf{a}, \mathbf{b}$ Photomicrograph, depicting an isolated head of a stage 53 tadpole (a $\mathbf{a}_{\mathbf{1}}$, a schematic transverse section of the hindbrain $\left(\mathbf{a}_{\mathbf{2}}\right)$, and a cross-sectioned head (b) at a rostro-caudal level indicated by the trapezoid in $\mathbf{a}_{\mathbf{1}}$; red and blue circles and arrows in $\mathbf{a}_{\mathbf{2}}$ indicate movements of the $\mathrm{O}_{2}$ electrode within the grid (white dots in $\mathbf{b}$ ), used to construct the $\mathrm{O}_{2}$ profile (b). $\mathbf{c}$ Dual recordings of $\mathrm{O}_{2}$ concentrations in the bath and above the floor of the $\mathrm{IV}^{\text {th }}$ ventricle in steps of $0.2 \mathrm{~mm}$. $\mathbf{d} \mathrm{O}_{2}$-concentration profile (mean \pm SEM) of a midline depth track above the $\mathrm{IV}^{\text {th }}$ ventricle $\left(\mathbf{a}_{\mathbf{2}}\right)$ in control (intact; color-coded) and metabolically inactive (EtOH-fixated; gray) preparations. e, f Recording of the ventricular $\mathrm{O}_{2}$ concentration in an EtOH-fixated preparation (e) during temporary increase of the bath $\mathrm{O}_{2}$ level

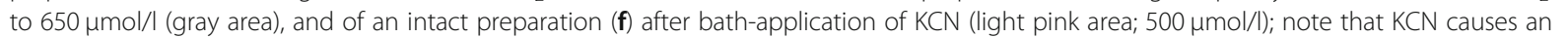
adjustment of the ventricular $\mathrm{O}_{2}$ level to the bath $\mathrm{O}_{2}$ level (single arrow in $\mathbf{f}$ ) that remains matched (double arrow in $\mathbf{f}$ ) when the bath $\mathrm{O}_{2}$ level is further increased (dark pink area). g Boxplot, depicting $\mathrm{O}_{2}$ concentrations in air-saturated bath solution (black), at the ventricular floor (red), and within the hindbrain (blue) in controls, in EtOH-fixated and KCN-treated preparations; note that EtOH-fixation and bath-application of KCN cause a significant increase of ventricular $\mathrm{O}_{2}$ concentrations to bath Ringer levels (*** $p<0.0001$; Mann-Whitney $U$ test). $\mathbf{h}$ Scatter plot depicting coinciding ventricular and bath $\mathrm{O}_{2}$ levels in metabolically inactive (black dots, EtOH-fixated) or oxidative phosphorylation-impaired (pink dots, KCN) preparations. $\mathrm{O}_{2}$ levels in $\mathbf{b}-\mathbf{f}$ are color-coded from blue $(0 \mu \mathrm{mol} / \mathrm{l})$ to red $(300 \mu \mathrm{mol} / \mathrm{l})$ to yellow $(600 \mu \mathrm{mol} / \mathrm{l})$; transverse hindbrain schemes indicate motion $(\mathbf{c})$ or position (e, $\mathbf{f}$ ) of the $\mathrm{O}_{2}$ electrode. OT, optic tectum; R, rostral; C, caudal; SC, spinal cord; $N$, number of preparations 
Fig. 1b), while the interior of the $I V^{\text {th }}$ ventricle was entirely devoid of $\mathrm{O}_{2}$ (blue in Fig. 1b). Stepwise measurements along a depth track in the midline of the brain (in steps of $200 \mu \mathrm{m}$ ) in a typical example (Fig. 1c) illustrated the gradual reduction in $\mathrm{O}_{2}$ concentration (blue color) as the electrode approached the floor of the IV ${ }^{\text {th }}$ ventricle (ventricular electrode), while the Ringer in the recording chamber at a distance of $5 \mathrm{~mm}$ from the isolated preparation (bath electrode) remained at the same airsaturated level. This systematic difference in the $\mathrm{O}_{2}$ concentration between bath solution and ventricle was significant and observed in all preparations (control in Fig. 1g). Repetitive measurements along the depth track above the floor of the $\mathrm{IV}^{\text {th }}$ ventricle in a number of preparations $(N=31)$ confirmed the reproducibility of the gradient as indicated by the small variability (intact in Fig. 1d).

In order to demonstrate that metabolic activity in the hindbrain causes $\mathrm{O}_{2}$ depletion in the adjacent $\mathrm{IV}^{\text {th }}$ ventricle, some isolated preparations were fixated in $70 \%$ ethanol overnight ( $N=7$ preparations) and reused for $\mathrm{O}_{2}$ measurements. As the electrode along the depth track (gray area in Fig. 1d) approached the ventricular floor in these fixated preparations, the $\mathrm{O}_{2}$ concentration remained at the same level as the air-saturated Ringer solution in the bath (EtOH in Fig. 1d, g). Moreover, an increase of the $\mathrm{O}_{2}$ concentration in the bath (gray area) in these metabolically inactive preparations to $600 \mu \mathrm{mol} / \mathrm{l}$ over a period of $\sim 5 \mathrm{~min}$ as illustrated by the typical example in Fig. 1e (bath electrode) caused a delayed, but similar increase of the ventricular $\mathrm{O}_{2}$ concentration. The time to reach $95 \%$ of the steady-state level was $\sim 15$ min $(14.8 \pm 0.3 \mathrm{~min}$; mean $\pm \mathrm{SEM} ; N=7$ preparations) and thus slower than the augmentation of the $\mathrm{O}_{2}$ level in the bath, due to the $\mathrm{O}_{2}$ diffusion into the ventricle. A comparable, matching dynamic of the $\mathrm{O}_{2}$ levels in the bath and the ventricle was observed during the return of the $\mathrm{O}_{2}$ concentration to air-saturated bath Ringer levels (right side in Fig. 1e). These findings suggest that (1) the shape of the $I^{\text {th }}$ ventricle generally poses no physical barrier for an increase/decrease of the $\mathrm{O}_{2}$ concentration when the bath $\mathrm{O}_{2}$ level is altered and that (2) the anoxic condition inside the ventricular compartment in intact preparations likely derives from the $\mathrm{O}_{2}$ consumption by the metabolically active tissue in the vicinity. In fact, measurements of the $\mathrm{O}_{2}$ concentration inside the hindbrain in functionally intact preparations exhibited similarly low levels as observed at the ventricular floor (compare ventr. and brain in Fig. 1g).

A causal relationship between the $\mathrm{O}_{2}$ consumption by the brain and the depleted ventricular $\mathrm{O}_{2}$ concentrations was further confirmed after impairing mitochondrial activity by bath-application of potassium cyanide $(\mathrm{KCN}$; $N=8$ preparations), which blocks cytochrome oxidase (complex IV) activity as the dominating $\mathrm{O}_{2}$-consuming process [34]. Bath application of $500 \mu \mathrm{mol} / \mathrm{l} \mathrm{KCN} \mathrm{(light}$ pink area in Fig. 1f) at air-saturated $\mathrm{O}_{2}$ concentrations of the bath Ringer solution $(\sim 290 \mu \mathrm{mol} / \mathrm{l}$; bath electrode in Fig. 1f) gradually increased the $\mathrm{O}_{2}$-depleted ventricular level to a concentration that matched bath levels (ventricular electrode in Fig. 1f), compatible with the consequences of a complete block of the major $\mathrm{O}_{2}$-consuming metabolic processes. Further increase of the $\mathrm{O}_{2}$ level in the bath Ringer to $>500 \mu \mathrm{mol} / \mathrm{l}$ in the continuous presence of KCN (dark pink area in Fig. 1f) caused a delayed but matching augmentation of ventricular and bath $\mathrm{O}_{2}$ concentrations. Thus, in the absence of metabolic activity in the brain, either by fixation of the tissue with $\mathrm{EtOH}$ (Fig. 1e) or by bath-application of KCN (Fig. 1f), the normally $\mathrm{O}_{2}$-depleted ventricular compartment gradually reaches and maintains the same $\mathrm{O}_{2}$ level as the bath solution (see EtOH and $\mathrm{KCN}$ in Fig. 1g, h). Therefore, the negligible $\mathrm{O}_{2}$ concentration in metabolically unimpaired preparations likely reflects the $\mathrm{O}_{2}$ consumption by the brain, which directly relates to the anoxic level in the ventricle (compare ventr. and brain in Fig. 1g). Thus, the relatively hypoxic state of the ventricle is likely no pathological condition but rather an expression of the capacity of brain tissue to utilize efficiently all available $\mathrm{O}_{2}$. Accordingly, $\mathrm{O}_{2}$ meaurements in the $\mathrm{IV}^{\text {th }}$ ventricle represent an excellent proxy to monitor changes in $\mathrm{O}_{2}$ consumption by the brain with the additional benefit that the neuronal tissue remains undamaged since the tip of the $\mathrm{O}_{2}$ electrode is positioned in the ventricular compartment.

\section{Consequences of alterations in bath Ringer oxygenation}

The almost anoxic condition of the brain tissue, reflected by the level in the $\mathrm{IV}^{\text {th }}$ ventricle, prompted us to evaluate the consequences of elevated $\mathrm{O}_{2}$ concentrations in the bath solution on the $\mathrm{O}_{2}$ level in the tissue. In isolated preparations, under control condition with air-saturated bath Ringer solution $(\sim 290 \mu \mathrm{mol} / \mathrm{l}$; bath electrode, left in Fig. 2a), the $\mathrm{O}_{2}$ electrode monitored the typical anoxic level as the electrode approached the floor of the IV ${ }^{\text {th }}$ ventricle (left in Fig. 2a). During stepwise increases of the $\mathrm{O}_{2}$ level in the bath solution (gray areas in Fig. 2a) to $\sim 550 \mu \mathrm{mol} / \mathrm{l}$ (light gray area), to $\sim 750 \mu \mathrm{mol} / \mathrm{l}$ (gray area) and to $\sim 950 \mu \mathrm{mol} / \mathrm{l}$ (dark gray area), the ventricular $\mathrm{O}_{2}$ level of the typical example, shown in Fig. 2a, increased gradually to $\sim 100 \mu \mathrm{mol} / \mathrm{l}$, to $\sim 150 \mu \mathrm{mol} / \mathrm{l}$, and to $\sim 350 \mu \mathrm{mol} / \mathrm{l}$, respectively (see $\mathrm{O}_{2}$ values at $1.2=$ bath level and $0=$ ventricular floor in Fig. 2a). Confirmation of the validity of higher ventricular $\mathrm{O}_{2}$ measurements when increasing the $\mathrm{O}_{2}$ level in the bath Ringer was provided by a temporally brief retrieval of the electrode to $1.2 \mathrm{~mm}$ above the floor of the IV ${ }^{\text {th }}$ ventricle (* in Fig. 2a), 


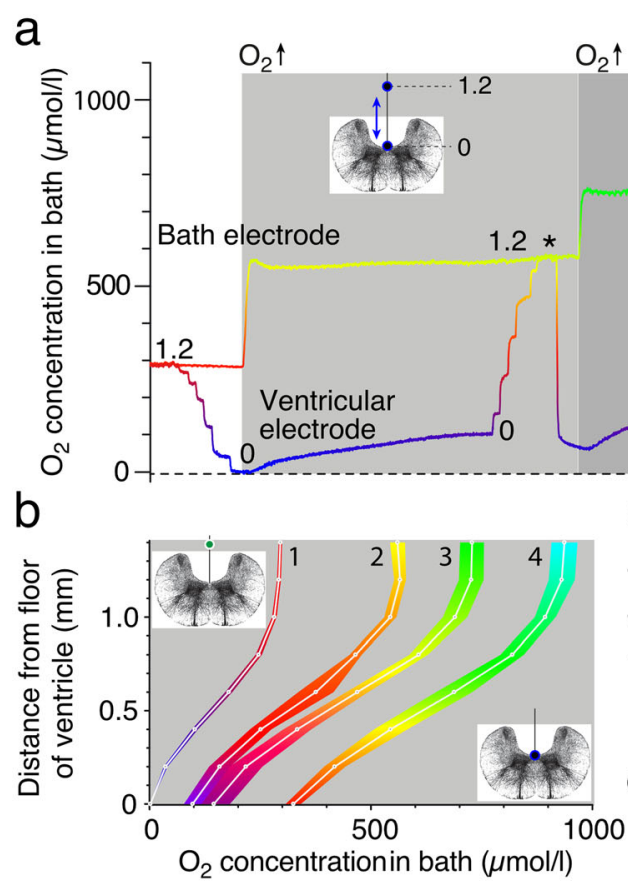

$\mathrm{O}_{2} \uparrow \quad \mathrm{O}_{2} \uparrow$
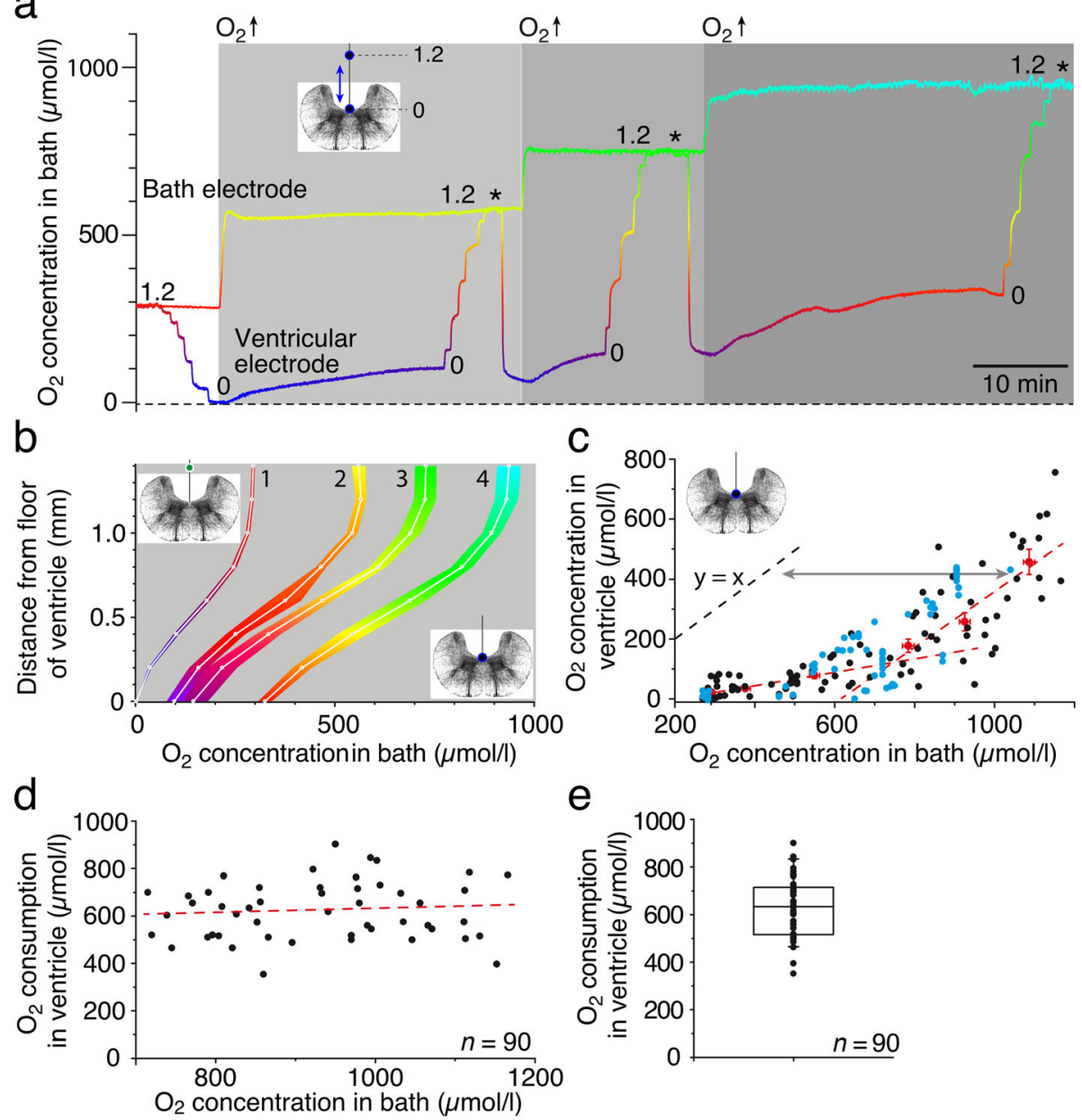

e

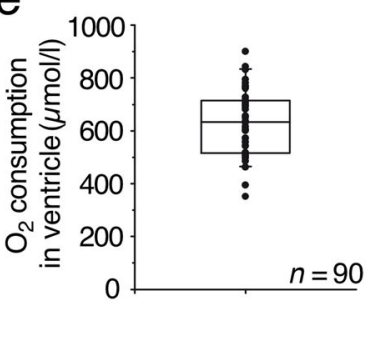

Fig. 2. Influence of bath $\mathrm{O}_{2}$ concentrations on ventricular $\mathrm{O}_{2}$ levels. a Recording of $\mathrm{O}_{2}$ levels in the bath and ventricle following stepwise increase of the bath $\mathrm{O}_{2}$ concentration from $\sim 290 \mu \mathrm{mol} / \mathrm{l}$ (air-saturated) to $\sim 550 \mu \mathrm{mol} / \mathrm{l}$ (light gray area), $750 \mu \mathrm{mol} / \mathrm{l}$ (gray area), and $\sim 950 \mu \mathrm{mol} /$ I (dark gray area); the $\mathrm{O}_{2}$-electrode was initially advanced to the ventricular floor in $0.2 \mathrm{~mm}$ steps (left in $\mathbf{a}$ ) and transiently repositioned to $1.2 \mathrm{~mm}$ above the floor $\left(^{*}\right)$ prior to each increase of the bath $\mathrm{O}_{2}$ concentration. $\mathbf{b} \mathrm{O}_{2}$ concentration profiles (mean $\pm \mathrm{SEM}$ ) of ventricular depth tracks (see insets) in air-saturated $(\sim 290 \mu \mathrm{mol} / \mathrm{l})$ bath solution $(1 ; N=31)$ and after the increase of the bath $\mathrm{O}_{2}$ concentration to $\sim 550 \mu \mathrm{mol} / \mathrm{l}(2 ; N=6)$, $750 \mu \mathrm{mol} / \mathrm{l}(3 ; \mathrm{N}=6)$, and $\sim 950 \mu \mathrm{mol} / \mathrm{l}(4 ; \mathrm{N}=6)$. c Scatter plot, depicting the dependency of the ventricular $\mathrm{O}_{2}$ concentration (black and red dots; $n=97$ from 24 preparations) and adjacent hindbrain (blue dots; $n=69$ from 11 preparations) from bath $\mathrm{O}_{2}$ levels; red dots represent the mean \pm SEM of the ventricular $\mathrm{O}_{2}$ level at distinct bath $\mathrm{O}_{2}$ concentrations and the red dashed lines linear regressions through the lower $\left(r^{2}=0.98\right)$ and higher $\left(r^{2}=0.96\right)$ range of mean ventricular concentrations, respectively. $\mathbf{d}$, e Scatter plot $(\mathbf{d})$ and boxplot $(\mathbf{e})$ depicting ventricular $\mathrm{O}_{2}$ consumption as function of the bath $\mathrm{O}_{2}$ level for concentrations $>700 \mu \mathrm{mol} / \mathrm{l}$ ( $n=90$ from 13 preparations) with a mean $\pm \mathrm{SEM}$ of $626 \pm 13 \mu \mathrm{mol} /$ I (e); the slope of the regression line in $\mathbf{d}\left(r^{2}=0.007\right)$ is not significantly different from zero $(p=0.42)$. $\mathrm{O}_{2}$ levels in $\mathbf{a}$ and $\mathbf{b}$ are color-coded from blue $(0 \mu \mathrm{mol} / \mathrm{l})$ to red $(300 \mu \mathrm{mol} / \mathrm{l})$ to yellow $(600 \mu \mathrm{mol} / \mathrm{l})$ to green $(750 \mu \mathrm{mol} / \mathrm{l})$ to cyan $(900 \mu \mathrm{mol} / \mathrm{l})$; transverse hindbrain schemes indicate motion (a) or position (b, c) of the $\mathrm{O}_{2}$ electrode. $N$, number of preparations; $n$, number of measurements

a position where the $\mathrm{O}_{2}$ concentration reflects the bath solution.

Plots of dorso-ventral depth tracks along the midline of the hindbrain (schemes in Fig. 2b) with varying starting $\mathrm{O}_{2}$ levels of the bath Ringer, i.e., $290 \mu \mathrm{mol} / \mathrm{l}$ (air-saturated), $550 \mu \mathrm{mol} / \mathrm{l}, 750 \mu \mathrm{mol} / \mathrm{l}$, and $950 \mu \mathrm{mol} / \mathrm{l}$ (see $1-4$ in Fig. 2b) generally revealed very similar shapes of the gradients when the $\mathrm{O}_{2}$ electrode approached the ventricular floor. However, at variance with the control condition where the ventricular floor was found to be anoxic (1 in Fig. 2 b; $N=31$ preparations), elevated bath Ringer $\mathrm{O}_{2}$ levels were accompanied by gradually higher $\mathrm{O}_{2}$ concentrations at the ventricular floor (2-4 in Fig. 2b; $N=6$ preparations, each). Interestingly, however, increases of the $\mathrm{O}_{2}$ concentration in the bath Ringer from $\sim 290 \mu \mathrm{mol} / \mathrm{l}$ to $\sim 750 \mu \mathrm{mol} / \mathrm{l}$ caused only a small augmentation by $\sim 150 \mu \mathrm{mol} / \mathrm{l}$ at the ventricular surface (left red dashed line in Fig. 2c), whereas further increases of the bath $\mathrm{O}_{2}$ level to $\sim 1200 \mu \mathrm{mol} / \mathrm{l}$ proportionally augmented the ventricular $\mathrm{O}_{2}$ level (right red dashed line in 
Fig. 2c). The small increase of ventricular $\mathrm{O}_{2}$ levels with bath levels up to $\sim 750 \mu \mathrm{mol} / \mathrm{l}(y=0.25 \mathrm{x})$ suggests that the brain consumes most of the available $\mathrm{O}_{2}$. The slope close to unity $(y=0.93 \mathrm{x})$ for bath Ringer $\mathrm{O}_{2}$ levels above $\sim 750 \mu \mathrm{mol} / \mathrm{l}$ suggests that additionally provided $\mathrm{O}_{2}$ through the bath Ringer remains unused by the brain tissue and thus appears as corresponding increase of the ventricular $\mathrm{O}_{2}$ level (Fig. 2c). Calculating and plotting of the ventricular $\mathrm{O}_{2}$ consumption as difference between bath and actual ventricular $\mathrm{O}_{2}$ level (Fig. $2 \mathrm{~d} ; n=90$ measurements from 13 preparations) for bath $\mathrm{O}_{2}$ concentrations $>700 \mu \mathrm{mol} / \mathrm{l}$, indicated that the consumed $\mathrm{O}_{2}$, although variable between preparations, is rather constant above this level as indicated by the linear regression with a slope that is not significantly different from zero (red dashed line in Fig. 2d; $p=0.42$ ). Accordingly, the ventricular $\mathrm{O}_{2}$ consumption at bath levels between 700 and $1200 \mu \mathrm{mol} / \mathrm{l}$ was in the range of $\sim 600 \mu \mathrm{mol} / \mathrm{l}$ (Fig. 2e). Importantly, $\mathrm{O}_{2}$ measurements within the adjacent hindbrain (blue circles in Fig. 2c) exhibited a very similar dependency from the bath Ringer $\mathrm{O}_{2}$ level, as the ventricle (black circles in Fig. 2c), indicating again that measurements in the latter compartment represent an excellent, minimal-damaging proxy for the $\mathrm{O}_{2}$ level of the adjacent central nervous tissue independent of the oxygenation level of the bath.

\section{Correlation between ventricular $\mathrm{O}_{2}$ levels and neuronal activity}

The major $\mathrm{O}_{2}$-consuming element in the brain are neurons, where oxidative phosphorylation is used to provide energy equivalents such as ATP to ensure the maintenance of the resting potential as well as the generation of inhibitory and excitatory responses including action potentials [5]. In fact, spike discharge and associated cellular homeostasis of the underlying conductances require the availability of considerable amounts of $\mathrm{O}_{2}$-dependent energy equivalents. This allows establishing a correlation between neuronal activity and $\mathrm{O}_{2}$ consumption. In fish and amphibians, MS-222, a tricaine derivate, is a potent blocker of action potentials through a prevention of activating the fast sodium conductance [35] and as such regularly used for the anesthesia of aquatic anamniotes [36]. To estimate the amount of $\mathrm{O}_{2}$ consumption in relation to neuronal activity in isolated Xenopus tadpole preparations, we employed extracellular recordings of multi-unit spike discharge of the superior oblique eye muscle-innervating motor nerve [37]. The superior oblique nerve resting discharge (lower black trace "before" in Fig. 3a) largely depends on inner ear afferent discharge and the corresponding spike activity of central vestibular neurons that tonically activate superior oblique motoneurons [38]. Both neuronal populations are located in the rostral hindbrain [39], in close proximity to the location of the ventricular $\mathrm{O}_{2}$ electrode. Accordingly, the extracellularly recorded multi-unit spike discharge of the superior oblique nerve provides a suitable correlate or proxy for central neuronal activity in a brain region adjacent to the $\mathrm{IV}^{\text {th }}$ ventricle.

Bath application of 0.5\% MS-222 for 15 min (pink area in Fig. 3a) reliably abolished the spontaneous discharge of the superior oblique nerve (black trace 'No spike discharge' and red trace in Fig. 3a). This effect was robust and required after the beginning of the washout $\sim 3 \mathrm{~h}$ until the resting discharge was completely reestablished (black trace "recovery" and red trace in Fig. 3a). During MS-222 application, the typical anoxic condition at the ventricular floor transiently increased (green trace in Fig. 3a) in parallel with the cessation of the superior oblique nerve resting discharge (red trace in Fig. 3a). In the presence of a stable bath Ringer $\mathrm{O}_{2}$ level (upper black trace in Fig. 3a), this suggests that the $\mathrm{O}_{2}$ consumption of the neuronal tissue in the vicinity of the $\mathrm{O}_{2}$ electrode temporarily decreased (blue trace in Fig. 3a) in agreement with the MS-222provoked blockage of neuronal activity. The augmentation of the ventricular $\mathrm{O}_{2}$ level following bathapplication of $0.5 \%$ MS-222 was observed in all experiments $(N=6$ preparations), reaching an average ventricular $\mathrm{O}_{2}$ level of $\sim 150 \mu \mathrm{mol} / \mathrm{l}$ (blue box in Fig. 3b) that significantly differed from the low $\mathrm{O}_{2}$ level prior to MS-222 administration $(p<0.0001$; Mann-Whitney $U$ test). In contrast to the profound and relatively longlasting effect of $0.5 \%$ MS-222, bath-application of a tenfold smaller concentration of MS-222 (0.05\%) also provoked a smaller $(\sim 20 \mu \mathrm{mol} / \mathrm{l})$, yet still significant increase of ventricular $\mathrm{O}_{2}$ levels $(p<0.0001$; MannWhitney $U$ test; $N=5$ preparations; green box in Fig. 3b), a more transient block of the superior oblique motor nerve activity and a faster recovery to the anoxic control levels (not shown). The consistency of the dose-dependent drug effect across experiments was confirmed by construction of the $\mathrm{O}_{2}$-depth profile in the presence of $0.05 \%$ and $0.5 \%$ MS-222, respectively, illustrating the differential alteration of the gradient as the $\mathrm{O}_{2}$ electrode approached the ventricular floor (Fig. 3c). Thus, MS-222-provoked blockage of neuronal activity caused a reduced $\mathrm{O}_{2}$ consumption of the central nervous tissue confirming that action potential generation and associated maintenance of ion homeostasis is a dominant $\mathrm{O}_{2}$-consuming process in the brain, which is further elaborated in the discussion. The absence of firing rate recovery during the initial washout phase with a relatively early increase in $\mathrm{O}_{2}$ consumption might be related to the fact that MS-222 also blocks tetrodotoxin-insensitive Nav-type sodium channels, even though at lower affinity [40]. These ion channels are not involved in action potential generation but 

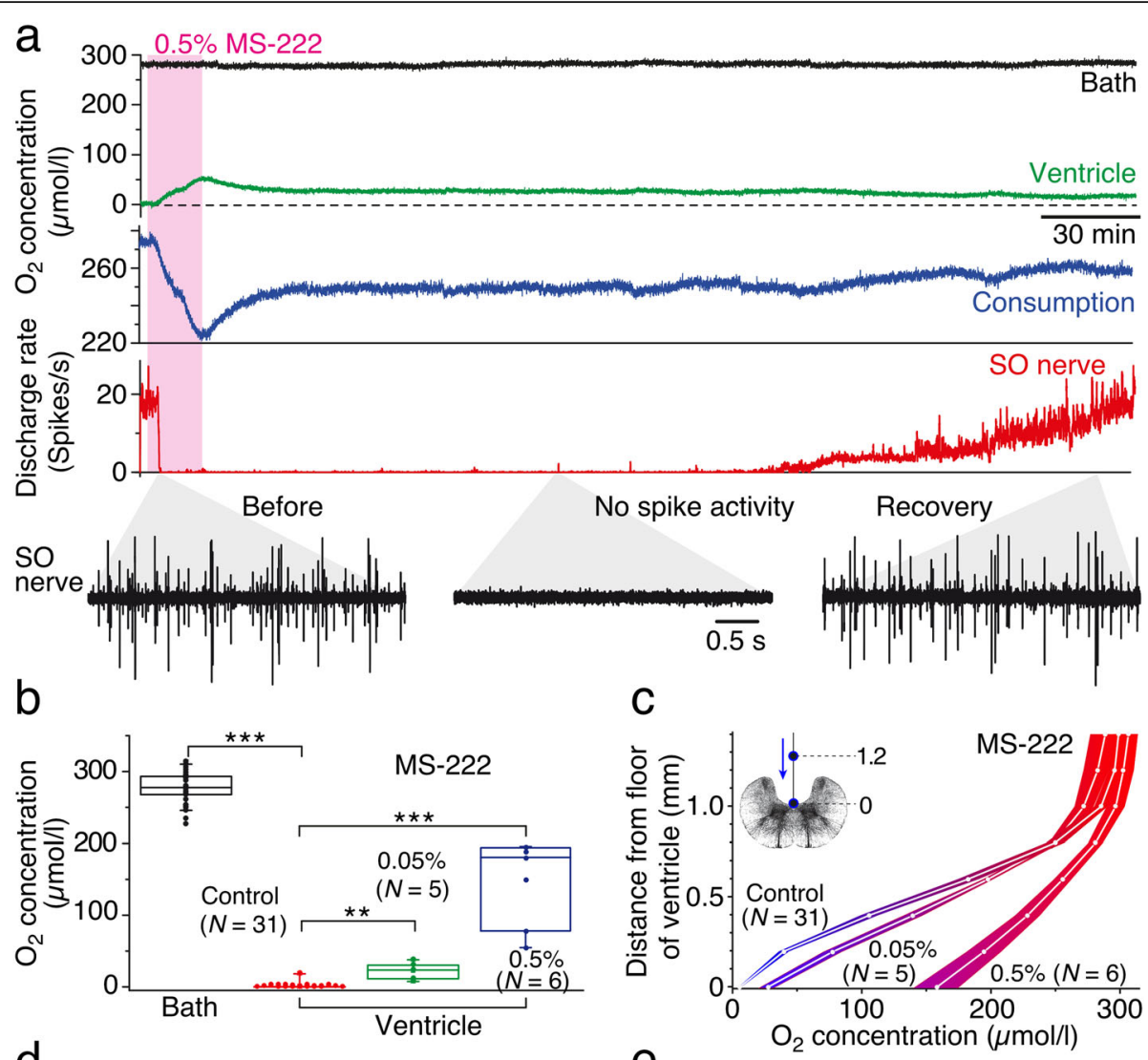

d

e
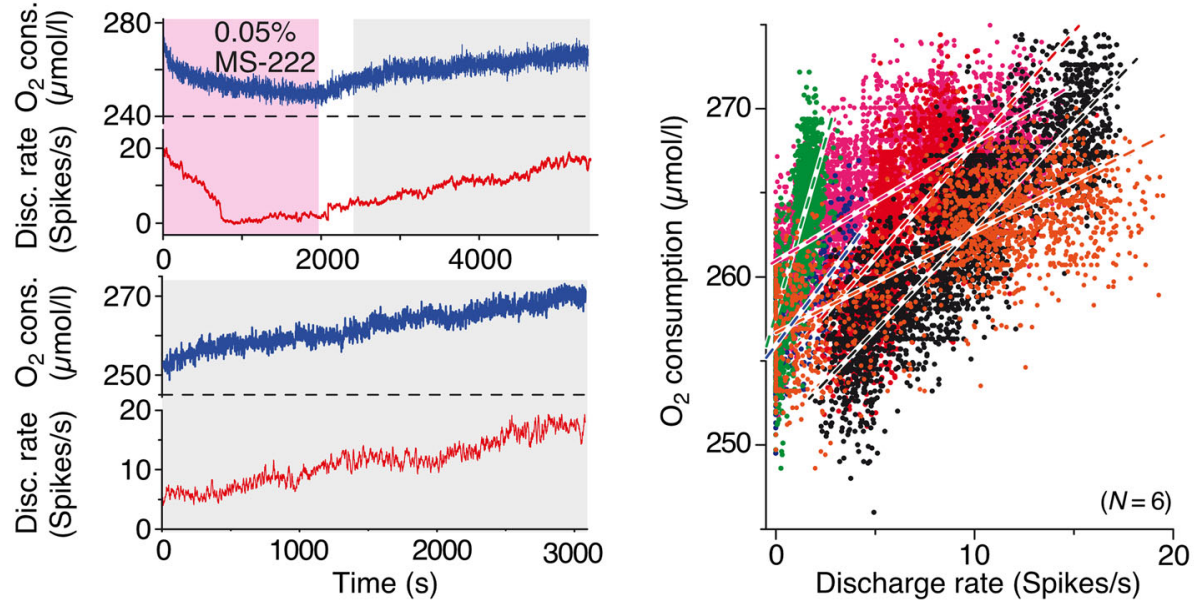

Fig. 3. Correlation between neuronal discharge and ventricular $\mathrm{O}_{2}$ concentration. a Recording of $\mathrm{O}_{2}$ levels in the bath (top black trace) and ventricle (green trace) along with the resting rate (red trace) of superior oblique nerve spike activity illustrated at extended time scales (black traces) for selected periods before (before), after spiking has been blocked by bath-applied (0.5\%; pink area) MS-222 (no spike activity), and during recovery (recovery); the $\mathrm{O}_{2}$ consumption (blue trace) was calculated as the difference of concurrent bath and ventricular $\mathrm{O}_{2}$ concentrations. b Boxplot, depicting $\mathrm{O}_{2}$ concentrations in the bath (black) and ventricle in controls (red; $N=31$ ) and after bath-application of $0.05 \%$ (green; $N=5$ ) and $0.5 \%$ MS-222 (blue; $N=6$ ) indicating significantly increased ventricular $\mathrm{O}_{2}$ levels when the spike activity was blocked $\left({ }^{* *} p<0.001\right.$; ${ }^{* * *} p<0.0001$; Mann-Whitney $U$ test. c $\mathrm{O}_{2}$ concentration profile (mean $\pm \mathrm{SEM}$ ) of a midline depth track above the floor of the $\mathrm{IV}^{\text {th }}$ ventricle in controls and after bath-application of $0.05 \%$ and $0.5 \%$ MS-222. $\mathbf{d} \mathrm{O}_{2}$ consumption (upper blue trace), calculated from $\mathrm{O}_{2}$ concentrations of the bath Ringer and ventricle and corresponding superior oblique nerve discharge rate (upper red trace) during and after bath application of 0.05\% MS-222 (pink area); lower traces illustrate the $\mathrm{O}_{2}$ consumption (blue) and resting rate (red) during the recovery from the drug effect at an extended time and amplitude scale (gray area from above). e Scatter plot, depicting the dependency of calculated $\mathrm{O}_{2}$ consumption on the resting rate of the superior oblique nerve during recovery from a 0.5\% MS-222-induced block of spike activity $(N=6)$; data from individual preparations are color-coded; each linear regression line has a slope that is significantly different from zero $(p<0.0001)$; green $\left(r^{2}=0.52\right)$, blue $\left(r^{2}=0.42\right)$, red $\left(r^{2}=0.40\right)$, black $\left(r^{2}=0.71\right)$, pink $\left(r^{2}=0.55\right)$, and orange $\left(r^{2}=0.69\right) . N$, number of preparations 


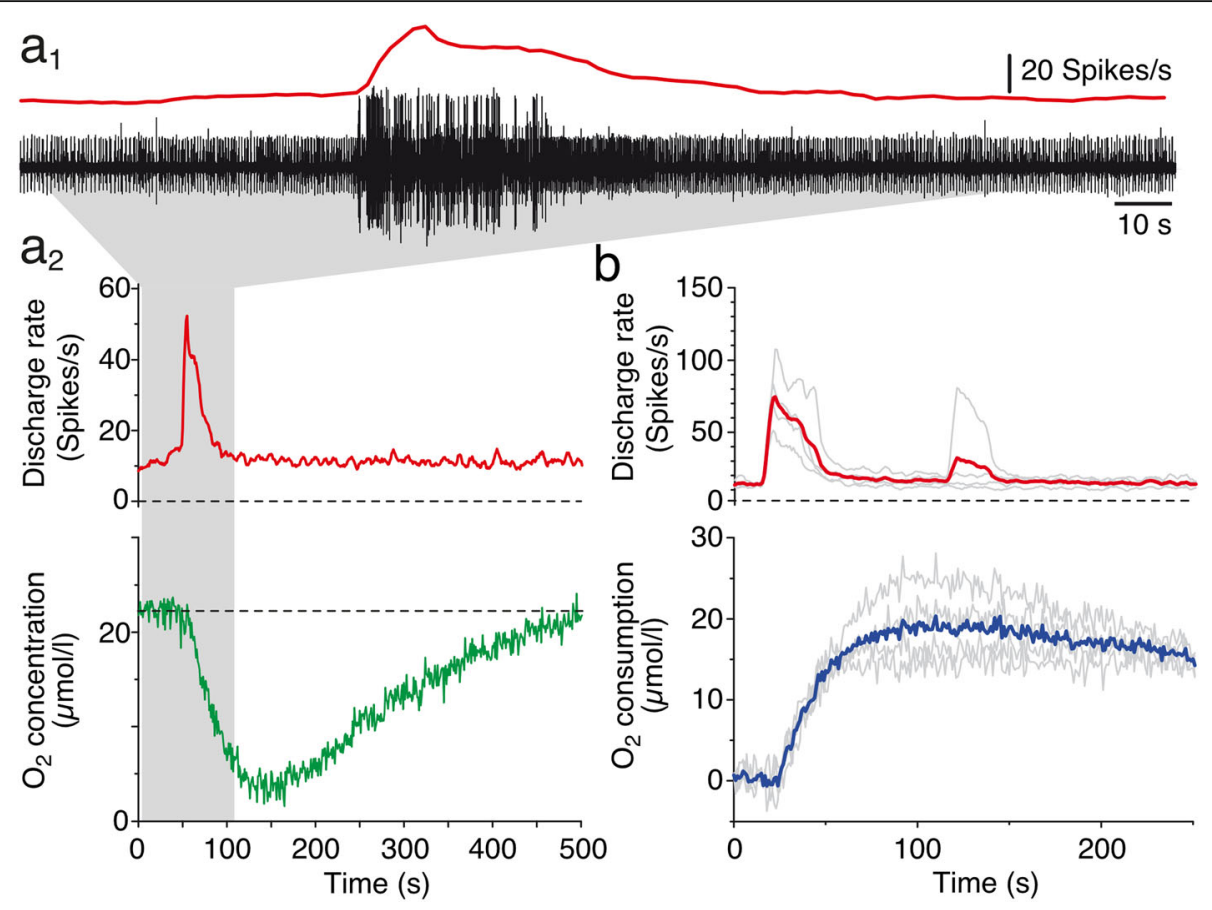

Fig. 4. Decrease of ventricular $\mathrm{O}_{2}$ concentrations during spontaneous spike bursts. a Typical multi-unit recording of the superior oblique nerve (black trace) and corresponding firing rate (red trace; bin width $1 \mathrm{~s}$ ), depicting a spontaneously occurring spike burst $\left(\mathbf{a}_{\mathbf{1}}\right)$. $\mathbf{a}_{\mathbf{2}}$ shows the transiently elevated discharge rate (red trace) of the multi-unit spike activity in $\mathbf{a}_{\mathbf{1}}$ (gray area) and concurrent alteration in ventricular $\mathrm{O}_{2}$ concentration (green trace) in an air-saturated bath solution. $\mathbf{b}$ Overlay of four consecutive spike burst episodes in an individual preparation (gray traces in the upper plot) and concurrent increases in ventricular $\mathrm{O}_{2}$ consumption (gray traces in the lower plot) along with the respective averages (red and blue traces)

contribute to the energy-consuming maintenance of the resting membrane potential.

A correlation between neuronal activity and $\mathrm{O}_{2}$ consumption was obtained during the final recovery phase of spike firing after bath-applied MS-222 had temporarily extinguished the resting discharge of the superior oblique nerve (Fig. 3d). The close correspondence of resting discharge rate (red trace in Fig. 3d) and concurrent ventricular $\mathrm{O}_{2}$ consumption (blue trace in Fig. 3d) in all experiments ( $N=6$ preparations) suggests that the increase in $\mathrm{O}_{2}$ consumption during the final washout phase of MS-222 is causally related to the parallel reacquisition of the spontaneous discharge. In fact, plotting the gradually increasing $\mathrm{O}_{2}$ consumption during this period with respect to the superior oblique nerve firing rate reveals a noisy, though clear, correlation between the two parameters (Fig. 3e). The variable slope of the linear regression in different preparations (color-coded dots in Fig. 3e) likely derives from the different magnitudes of spontaneous firing rates $(23.0 \pm 9.5$ spikes/s; mean \pm SD; $N=6$ preparations) and thus on the number of isolated axons in the multi-unit recordings. While this prevents a direct correlation of absolute $\mathrm{O}_{2}$ levels and distinct firing rates, it confirms nonetheless that changes in neuronal activity of the central nervous system are reflected in the alterations of the $\mathrm{O}_{2}$ consumption.

\section{Alterations of $\mathrm{O}_{2}$ consumption during spontaneous increases of neuronal discharge}

The activity of the superior oblique nerve consists of a multi-unit discharge $[37,41]$ with occasionally occurring bursts of action potentials that usually last $10-60 \mathrm{~s}$ as depicted in Fig. $4 \mathrm{a}_{1}$. These spontaneous spike bursts derive from sensory-motor transformations in central vestibular neurons in the hindbrain [41] and might thus also be mirrored by alterations of ventricular $\mathrm{O}_{2}$ levels. In fact, augmented superior oblique nerve spike rates (red trace in Fig. $4 a_{1}, a_{2}$ ) are accompanied by small but robust transient drops of the residual $\mathrm{O}_{2}$ level in the $\mathrm{IV}^{\text {th }}$ ventricle (green trace in Fig. $4 \mathrm{a}_{2}$ ), indicating a burstrelated temporary increase in $\mathrm{O}_{2}$ consumption (blue trace in Fig. 4b). Given the very low ventricular $\mathrm{O}_{2}$ concentrations in an air-saturated bath solution (see above), the spike burst-related increase in $\mathrm{O}_{2}$ consumption was consequently only in the range of $10-20 \mu \mathrm{mol} / \mathrm{l}$ as indicated by the averaged $\mathrm{O}_{2}$ transients during four consecutive spike bursts of different magnitudes in a given preparation over a period of $2 \mathrm{~h}$ (red and blue traces in Fig. 4b). The change in the $\mathrm{O}_{2}$ concentration had an average delay of $\sim 15 \mathrm{~s}(14.2 \pm 3.0 \mathrm{~s}$; mean \pm SEM; $N=6$ 
preparations) with respect to the onset of the spike burst and a time to peak of $\sim 100 \mathrm{~s}(98.2 \pm 10.3 \mathrm{~s}$; mean \pm SEM; $N=6$ preparations). The gradual return to baseline ventricular $\mathrm{O}_{2}$ levels usually required $\sim 10 \mathrm{~min}$ and appeared to be correlated with the magnitude and/or duration of the spike burst. However, the generally very low baseline $\mathrm{O}_{2}$ levels in the ventricular compartment under air-saturated bath conditions prevented a further correlation between magnitude/temporal extent of spike bursts and $\mathrm{O}_{2}$ consumption dynamics. Therefore, spike burst-related alterations of ventricular $\mathrm{O}_{2}$ concentrations were further analyzed in preparations that were maintained at various levels of elevated bath $\mathrm{O}_{2}$ levels.

Spontaneous episodes of spike bursts at higher bath Ringer and thus ventricular $\mathrm{O}_{2}$ levels were also accompanied by concurrent alterations in $\mathrm{O}_{2}$ concentrations (Fig. 5a), which however were considerably larger compared to those observed in air-saturated bath solutions. The overlay of ten representative spike burst episodes and concurrent $\mathrm{O}_{2}$ transients (gray traces in Fig. 5b) along with the respective averages in an individual preparation (red and blue traces in Fig. 5b) confirmed the impression of larger $\mathrm{O}_{2}$ transients with increased bath and thus ventricular $\mathrm{O}_{2}$ levels $(\sim 50 \mu \mathrm{mol} / \mathrm{l})$. The latencies of the $\mathrm{O}_{2}$ transients after spike burst onset (dashed vertical line and arrow in Fig. 5b) at higher bath $\mathrm{O}_{2}$ concentrations were similar to those measured in airsaturated solutions (Fig. 5c). In fact, the average onset of the $\mathrm{O}_{2}$ transients of $\sim 13 \mathrm{~s}(13.1 \pm 0.8 \mathrm{~s} ;$ mean \pm SEM; $n=69$ measurements in 10 preparations) was relatively independent of the $\mathrm{O}_{2}$ level in the ventricle (dashed line in Fig. $5 c ; p=0.61$ ).

A potential correlation between the magnitude of the spontaneous spike burst, associated $\mathrm{O}_{2}$ consumption and ventricular $\mathrm{O}_{2}$ level, was evaluated following calculation of the spike burst integral (light red areas in Fig. $5 d_{1}$ ) and the integral of the corresponding $\mathrm{O}_{2}$ transient (light green areas in Fig. $5 d_{1}$ ). Plotting the spike burst integral as a function of the ventricular $\mathrm{O}_{2}$ concentration (red circles and red dashed line in Fig. $5 \mathrm{~d}_{2} ; n=30$ measurements from 10 preparations) indicated that the extent of spontaneous spike discharge was independent of the ambient $\mathrm{O}_{2}$ level, since the slope of the linear regression was not significantly different from zero $(p=0.38)$. In contrast, the integral of the $\mathrm{O}_{2}$ transient increased with higher ventricular $\mathrm{O}_{2}$ levels (green circles and green dashed line in Fig. $5 \mathrm{~d}_{2}$ ) as indicated by the non-zero slope of the linear regression $(p<0.001)$, thus confirming the general impression of larger $\mathrm{O}_{2}$ transients when augmenting the bath $\mathrm{O}_{2}$ level (compare $\mathrm{O}_{2}$ transients in Figs. $4 \mathrm{~b}$ and $5 \mathrm{~b}$ ). Normalization of the integral of the $\mathrm{O}_{2}$ transient with respect to the corresponding spike burst integral yielded the $\mathrm{O}_{2}$-consumption rate (Fig. 5e). This procedure confirmed the observed significant increase (dashed line; $p<0.05$ ) of the $\mathrm{O}_{2}$ transient magnitude for spike burst episodes at higher ventricular $\mathrm{O}_{2}$ levels $(n=$ 30 measurements from 10 preparations). The larger consumption at higher ventricular $\mathrm{O}_{2}$ levels occurred despite the tendency (the slope of the linear regression was not significantly different from zero; $p=0.15$ ) of a generally faster recovery of the $\mathrm{O}_{2}$ transient to baseline levels ( $n=13$ measurements from 6 preparations) at more elevated ventricular $\mathrm{O}_{2}$ levels (Fig. 5f). Thus, the enhanced availability of $\mathrm{O}_{2}$ obviously dominates the increase of $\mathrm{O}_{2}$ consumption during spike bursts even though reacquisition of the baseline level occurs faster under these circumstances. These results represent a first demonstration of a clear correlation between spike firing magnitudes and $\mathrm{O}_{2}$ consumption in an isolated Xenopus preparation and as such the first step for further studies on more detailed aspects of the interrelation between brain activity and energy cost in such a model system (see the "Discussion" section below).

\section{Discussion}

$\mathrm{O}_{2}$ concentrations in the brain of isolated preparations of Xenopus tadpoles were close to zero in the $\mathrm{IV}^{\text {th }}$ ventricle and adjacent hindbrain in air-saturated bath solutions. Application of $\mathrm{KCN}$ or fixation with EtOH raised ventricular $\mathrm{O}_{2}$ concentrations to bath levels, indicating complete consumption of available $\mathrm{O}_{2}$ prior to the metabolic inactivation. Artificial augmentation of bath $\mathrm{O}_{2}$ levels increased ventricular $\mathrm{O}_{2}$ concentrations, which were proportional to those in the bath above $\sim 700 \mu \mathrm{mol} / \mathrm{l}$. Inhibition of spike activity and spontaneous bursts caused a reversible decrease and transient increase of the $\mathrm{O}_{2}$ consumption, respectively.

\section{Suitability of isolated preparations for correlating changes in $\mathrm{O}_{2}$ concentration and neuronal activity}

Direct in vivo measurements of $\mathrm{O}_{2}$ concentrations within specific compartments of the brain are usually very difficult if not impossible to obtain, mostly due to the virtual inaccessibility of the structure, the difficult targeted placement of $\mathrm{O}_{2}$ electrodes, the tedious maintenance of constant vital parameters of the animal, and the inability to alter $\mathrm{O}_{2}$ concentrations or neuronal activity in an experimentally controlled fashion. In vitro whole brain or head preparations of various vertebrate species with intact sensory organs, motor effectors, and central nervous circuits [27], which can be maintained for several days after isolation in ionically defined Ringer solutions, are highly suitable alternatives for in vivo measurements. The maintenance of isolated whole head preparations of Xenopus laevis tadpoles in Ringer solution [27] allows a controlled supply of $\mathrm{O}_{2}$ but also of other metabolically relevant molecules such as lactate or 

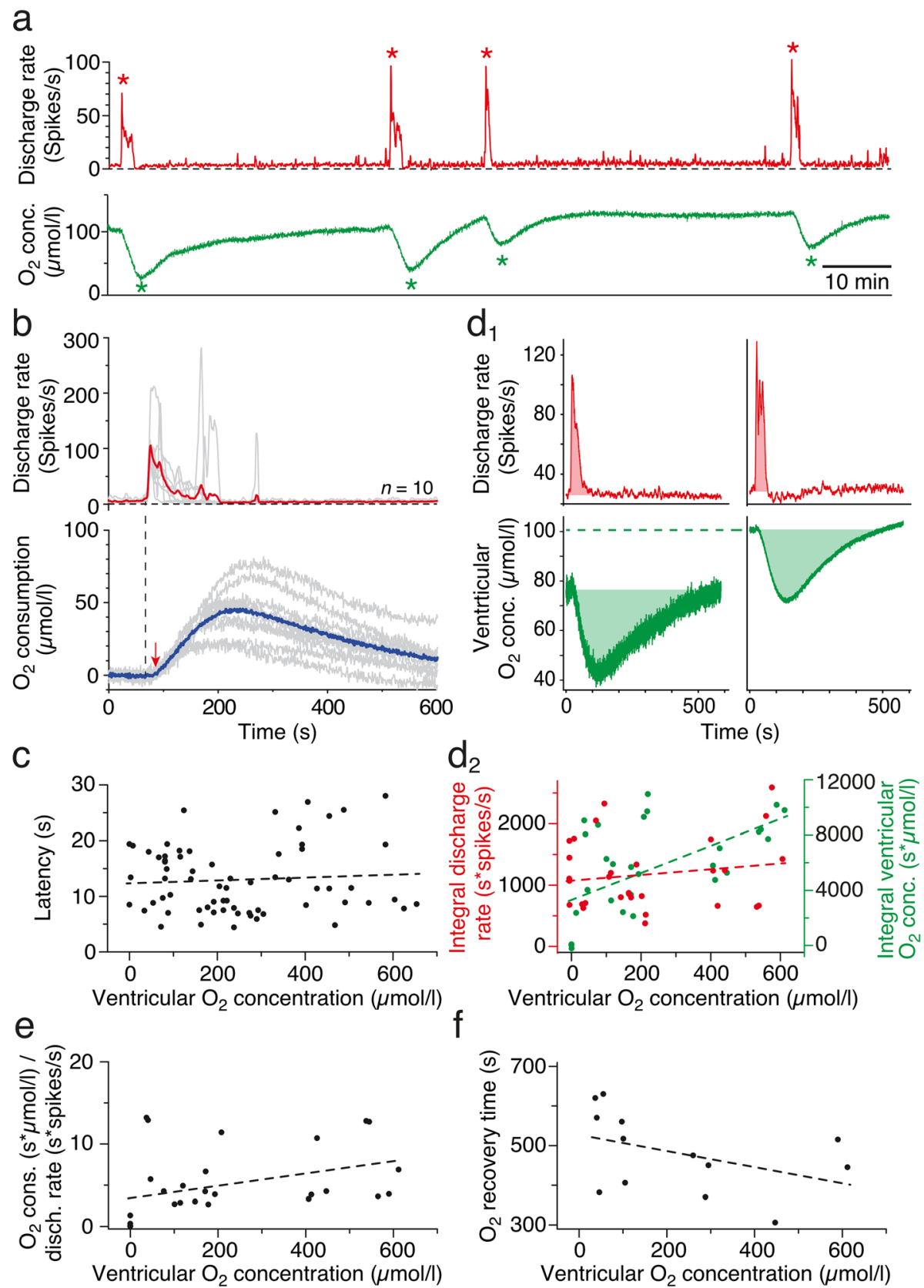

$\mathrm{d}_{2}$
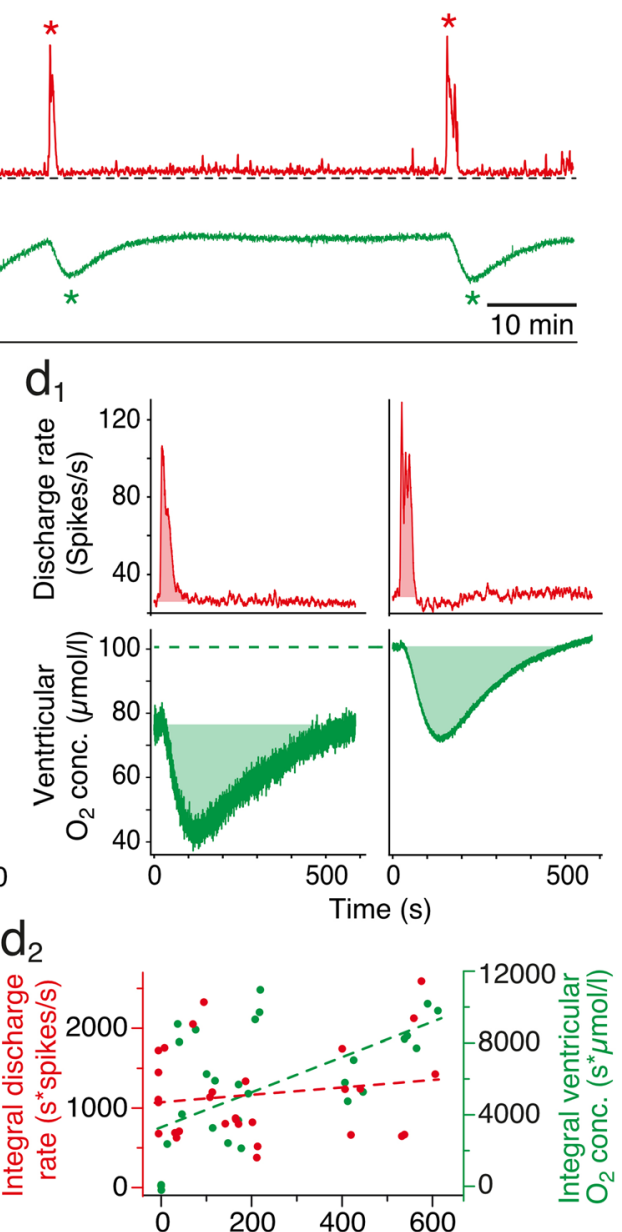

f

Ventricular $\mathrm{O}_{2}$ concentration $(\mu \mathrm{mol} / \mathrm{l})$

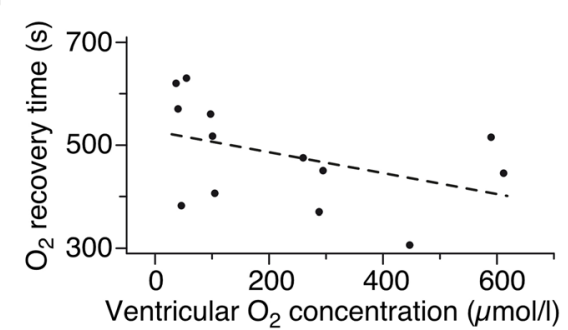

Fig. 5. Systematic correlation between neuronal activity and ventricular $\mathrm{O}_{2}$ levels. a Superior oblique nerve firing rate profile (red trace) of four successive spike bursts (red *) and concurrent alterations of the ventricular $\mathrm{O}_{2}$ concentration (green trace and *) at a ventricular $\mathrm{O}_{2}$ level of $100 \mu \mathrm{mol} / \mathrm{l}$. b Overlay of spike burst episodes $(n=10)$ from one preparation and corresponding increases in ventricular $\mathrm{O}_{2}$ consumption (gray traces in the upper and lower plot) along with the respective averages (red and blue traces); vertical dashed line and red arrow indicate the latency of the $\mathrm{O}_{2}$ transient relative to spike burst onset. c Latency of $\mathrm{O}_{2}$ transients ( $n=69$ from 10 preparations) as function of ventricular $\mathrm{O}_{2}$ concentrations; the slope of the linear regression was not significantly different from zero $\left(r^{2}=0.004 ; p=0.61\right)$. $\mathbf{d}$ Integrals of spike bursts and concurrent $\mathrm{O}_{2}$ transients (light red and light green areas in $\mathbf{d}_{\mathbf{1}}$, respectively) at a lower (left in $\mathbf{d}_{\mathbf{1}}$ ) and a higher ventricular $\mathrm{O}_{2}$ level (right in $\mathbf{d}_{\mathbf{1}}$; green dashed line); $\mathbf{d}_{\mathbf{2}}$ shows the dependency of spike burst (red circles) and $\mathrm{O}_{2}$ transient integrals (green circles) on ventricular $\mathrm{O}_{2}$ levels ( $n=30$ from 10 preparations); note that the integrals of the spike bursts were independent from (red dashed line; $r^{2}=0.03 ; p=0.38$ ), whereas those of the $\mathrm{O}_{2}$ transients significantly increased (green dashed line; $r^{2}=0.37 ; p<0.001$ ) with higher ventricular $\mathrm{O}_{2}$ levels. e, $\mathbf{f}$ Dependency of the ratio of $\mathrm{O}_{2}$ consumption and spike burst integral (e; $n=30$ from 10 preparations) and of the $\mathrm{O}_{2}$ recovery time (f) from ventricular $\mathrm{O}_{2}$ levels $(n=13$ from 6 preparations); note that the slope of the linear regression of the $\mathrm{O}_{2}$ /firing rate (e) was significantly different from zero $\left(r^{2}=0.14 ; p<0.05\right)$, whereas that of the $\mathrm{O}_{2}$ recovery $(\mathbf{f})$ was not $\left(r^{2}=0.18 ; p=0.15\right) . n$, number of measurements 
glucose through the temperature-, $\mathrm{pH}-$, and $\mathrm{O}_{2}$-controlled surrounding bath medium. The possibility to monitor and maintain major "vital" parameters at defined levels ensures reliable and repeatable measurements under control conditions and facilitates an estimation of the consequences of experimentally altered $\mathrm{O}_{2}$ concentrations (Fig. 2a). The bath chamber furthermore allows an easy and fast exchange of solutions and thereby application of blockers that impair metabolic (e.g., KCN; Fig. 1f) or neuronal activity (e.g., MS-222; Fig. 3a).

The plain visibility and accessibility of the central nervous system and its ventricular compartments in isolated preparations of Xenopus tadpoles (Fig. 1a; e.g., [36]) allow unimpaired, $\mu \mathrm{m}$-precise targeted placements of $\mathrm{O}_{2}$ - and electrophysiological recording electrodes within specific brain compartments. Moreover, the vitality and functionality of isolated amphibian brains or whole heads [27] allows monitoring in vivo-like behaviors by an in vitro approach. Motor behaviors such as tail-based swimming or eye movements [42] can be evoked by close-to-natural stimuli. The knowledge of the underlying sensory-motor pathways and respective neuronal computations represents the necessary prerequisite to link patterns of neuronal activity in defined circuits with the $\mathrm{O}_{2}$ /energy cost for respective cellular functions. The causal link between spontaneous extraocular motor spike bursts and subsequent increase in $\mathrm{O}_{2}$ consumption (Figs. 4 and 5) was in the current study only a first step in the attempt to calculate the energetic demand of neuronal activity for a specific motor behavior. Comparable correlations between spike activity and $\mathrm{O}_{2}$ tissue concentration $[9,10,12]$ or turnover of energy equivalents $[8,14,43]$ have been established for various neuronal populations in slice preparations. However, the latter, more reductionistic model system prevents assigning $\mathrm{O}_{2}$ consumption to the production of behaviorally relevant neuronal transformations or production of motor commands or behaviors. Isolated preparations of Xenopus tadpoles, which allow linking behavior-specific neuronal computations with concurrent alterations of $\mathrm{O}_{2}$ concentrations under controllable conditions, are therefore highly suitable to estimate the $\mathrm{O}_{2}$ /energy consumption for defined neuronal activities. In a next step, superior oblique motoneurons will be activated by visuo-vestibular stimulation (sensory activation or galvanic currents) to elucidate the $\mathrm{O}_{2}$ dynamics during natural activation of optokinetic and vestibuloocular reflexes in isolated tadpole preparations. The knowledge obtained by our study now allows framing the experimental conditions such that it will be possible to visualize the $\mathrm{O}_{2}$ consumption dynamics during a particular motor behavior.

\section{Correlation between bath and ventricular/brain $\mathrm{O}_{2}$ concentrations}

The amount of $\mathrm{O}_{2}$ consumed by an isolated preparation became immanent through the vertical profile of the $\mathrm{O}_{2}$ concentration above the head in the bath solution (Fig. 1b-d). While the $\mathrm{O}_{2}$ level in most of the bath volume is $\sim 290 \mu \mathrm{mol} / \mathrm{l}$ under air-saturated conditions (red color in Fig. 1b), a hovering vertical layer of $\sim 1.0 \mathrm{~mm}$ immediately above the brain and adjacent skull tissue reveals gradually lower $\mathrm{O}_{2}$ concentrations (violet in Fig. 1b) when approaching the tissue surface with the $\mathrm{O}_{2}$ electrode from above. The reduced $\mathrm{O}_{2}$ level signifies the sustained consumption by the viable tissue that is obviously faster than the resupply via diffusion from the bath, which is particularly obvious in the brain where the $I V^{\text {th }}$ ventricle and adjacent hindbrain is virtually anoxic (blue in Fig. 1b). Accordingly, the $\mathrm{O}_{2}$ consumption due to the metabolic activity generates a sink with a gradient perpendicular to the tissue surface that varies in slope with the bath $\mathrm{O}_{2}$ level (Fig. 2b). Inactivation of the tissue with $\mathrm{EtOH}$ (Fig. 1d) or KCN, a potent inhibitor of the cell respiratory chain, annihilates the $\mathrm{O}_{2}$ sink and thus abolishes the gradient.

Independent of the bath level, the $\mathrm{O}_{2}$ concentration in the $\mathrm{IV}^{\text {th }}$ ventricle and adjacent hindbrain were identical (compare black and blue circles in Fig. 2c). Moreover, increases of bath $\mathrm{O}_{2}$ levels caused concurrent alterations of the respective concentration in both compartments with similar dynamics and magnitude. This indicates that neither the surface nor cellular elements form a major barrier for $\mathrm{O}_{2}$ diffusion into the brain. Thus, $\mathrm{O}_{2}$ monitoring in the ventricular compartment directly reflects the $\mathrm{O}_{2}$ dynamics of the adjacent hindbrain tissue and has the advantage of not damaging the neuronal tissue. The delay to reach a new steady-state ventricular $\mathrm{O}_{2}$ level in metabolically inactive preparations $(\sim 15 \mathrm{~min}$; Fig. 1e) appears to be independent from the bath $\mathrm{O}_{2}$ level and is likely related to the consequence of the ventricular topography on $\mathrm{O}_{2}$ diffusion and thus likely reflects an amphibian brain-specific feature.

In air-saturated bath solutions, the $\mathrm{O}_{2}$ concentration in the ventricle and adjacent brain tissue was close to zero (Figs. 1 and 2). Similar low $\mathrm{O}_{2}$ levels were also observed in studies that employed mammalian slice preparations in air-saturated Ringer solutions [8, 26]. The virtual absence of $\mathrm{O}_{2}$ in isolated amphibian brains or mammalian brains in vivo [44, 45] is likely due to the efficient metabolic turnover of all available $\mathrm{O}_{2}$ to generate ATP. The virtual absence of $\mathrm{O}_{2}$ in the ventricular compartment up to bath $\mathrm{O}_{2}$ levels of $\sim 700 \mu \mathrm{mol} / \mathrm{l}$ in the current study (Fig. 2c), indicates a considerable capacity of the amphibian brain tissue to use $\mathrm{O}_{2}$ for oxidative phosphorylation. Utilization of $\mathrm{O}_{2}$ by this pathway complies with the equalization of ventricular and bath $\mathrm{O}_{2}$ 
levels following the application of $\mathrm{KCN}$, known to block mitochondrial activity. This identifies oxidative phosphorylation as the dominating if not exclusive $\mathrm{O}_{2}$-consuming process in the amphibian brain in compliance with the general importance of this metabolic pathway (e.g., [46]). The increase of the $\mathrm{O}_{2}$ concentration in the bath up to $1200 \mu \mathrm{mol} / \mathrm{l}$ without any larger alteration in the resting rate of the superior oblique nerve spike discharge excludes a potentially toxic effect of $\mathrm{O}_{2}$ up to this level. This allows testing the influence of $\mathrm{O}_{2}$ on the generation of ATP and neuronal computations over a relatively wide range.

\section{Correlation between $\mathrm{O}_{2}$ concentration and neuronal activity}

The rather low tissue $\mathrm{O}_{2}$ levels with bath $\mathrm{O}_{2}$ levels of up to $\sim 700 \mu \mathrm{mol} / \mathrm{l}$ indicates that the central nervous system, even under in vitro conditions, is obviously capable of consuming a considerable amount of $\mathrm{O}_{2}$, in compliance with findings in many other studies on $\mathrm{O}_{2}$ consumption $[10,45,46]$. While the substantial $\mathrm{O}_{2}$ consumption by brain tissue is well known, it is less clear, which cellular elements dominate the $\mathrm{O}_{2}$ turnover and how this is governed by the biophysical and morphological characteristics of the neuronal types involved. A number of studies, mostly on slice preparations, have demonstrated the necessity of adequate $\mathrm{O}_{2}$ levels for sustained neuronal activity and synaptic transmission [5, 12]. Other studies emphasize the need for considerable amounts of $\mathrm{O}_{2}$ to maintain neuron-specific resting membrane potential levels [24] and for the homeostasis of non-neuronal elements such as astrocytes [47, 48].

Bath application of the local anesthetic MS-222 in the current experiments, known to completely abolish spike discharge in fish and amphibians including isolated larval Xenopus preparations [36], also reduced the $\mathrm{O}_{2}$ consumption by $\sim 50 \%$ (Fig. 3b). The most parsimonious explanation is that the homeostasis related to spike generation and repolarization at least in the isolated amphibian brain under in vitro conditions consumes about half of the available $\mathrm{O}_{2}$ in air-saturated bath solutions. Moreover, the recovery of the superior oblique nerve spike discharge after an abolishment of action potentials by MS-222 was linearly correlated with the $\mathrm{O}_{2}$ consumption in all cases (Fig. 3e). However, the apparent lack of coherence of spike rates in different superior oblique nerves with respect to $\mathrm{O}_{2}$ consumption (color-coded dots in Fig. 3e) is mostly due to the large variability in the number of isolated units in these multi-unit recordings. Even though the superior oblique nerve discharge is only a proxy for central nervous spike activity, these measurements clearly infer causality and allow quantitative correlations between spike rate and $\mathrm{O}_{2}$ consumption. The somewhat dissociated correlation between ventricular $\mathrm{O}_{2}$ concentration and firing rate recovery during the first phase of MS-222 washout is potentially related to the block of ion channels, although with varying sensitivity, in addition to those that contribute to the action potential generation [40, 49]. Blocking these channels might for instance affect the membrane potential and, thereby, reduce the energy and thus $\mathrm{O}_{2}$ consumption for the maintenance of the resting membrane potential. This therefore requires a more differentiated and extended view on the link between spike discharge, resting membrane potential, and $\mathrm{O}_{2}$ consumption. On the other hand, the residual consumption of $\sim 50 \% \mathrm{O}_{2}$ in the presence of MS-222 indicates that glial cell metabolism and metabolic activity principally unrelated to action potential generation in neurons utilize a similar amount of $\mathrm{O}_{2}$ as required for neuronal spike firing. It is well known from mammalian systems that the maintenance of the resting membrane potential, non-signaling processes, and cellular housekeeping (e.g., maintenance of cytoskeleton and membrane structure) are metabolically demanding processes [23, 24, 50]. As an example, $\mathrm{O}_{2}$ consumption in mouse hippocampal slices was still substantial during tetrodotoxin-blocked action potentials [10]. A further contribution to $\mathrm{O}_{2}$ consumption during MS-222-blocked neuronal signaling might be attributed to $\mathrm{O}_{2}$ diffusion into neighboring areas, where blockage of neural firing might be incomplete, which, however, was not determined in the current study.

The amount of $\mathrm{O}_{2}$ to sustain neuronal spike discharge at rest increased further during spontaneous spike burst activity of the superior oblique nerve (Figs. 4 and 5). The discharge of this extraocular motor nerve is an excellent proxy for correlating increased neuronal activity with the $\mathrm{O}_{2}$ level measured within the $\mathrm{IV}^{\text {th }}$ ventricle because the major presynaptic cellular generators of these spike bursts are located in the spatially adjacent hindbrain vestibular nuclei and the superior oblique motor nucleus below the floor of the $\mathrm{IV}^{\text {th }}$ ventricle [39]. While the transient increase in $\mathrm{O}_{2}$ consumption is rather small in airsaturated bath solutions, due to the very low ventricular $\mathrm{O}_{2}$ levels, it becomes more pronounced at higher bath $\mathrm{O}_{2}$ concentrations. These larger $\mathrm{O}_{2}$ transients, however, are not due to an increase in spike burst magnitude but likely reflect an augmentation in the fractional contribution of oxidative phosphorylation to ATP production (compared to other pathways such as glycolysis (Fig. $5 \mathrm{~d}_{2}$ ). The magnitude as well as the onset of the $\mathrm{O}_{2}$ transient relative to the spike burst (13-15s) is independent of the ambient $\mathrm{O}_{2}$ concentration. However, this delay is slower compared to respective values reported in other, although mammalian, in vitro studies $[8,9]$ and potentially derives from the spatial dissociation of the measurement 
of the burst-relevant neuronal activity in the hindbrain and of $\mathrm{O}_{2}$ in the ventricle.

The quantifiable correlation between spike activity and $\mathrm{O}_{2}$ consumption in the current study represents an ideal condition to further evaluate the link between computational capability and metabolic activity in behaviorally relevant and morpho-physiologically characterized neural circuits. Isolated preparations such as employed here provide the accessibility to such networks for physiological recordings and calcium imaging while simultaneously offering the advantage to manipulate and measure $\mathrm{O}_{2}$ concentrations. Therefore, this study, using a novel model system, is only a first step in the attempt to better understand how metabolic requirements and constraints affect neuronal function. Future experiments using this model system will exploit the accessibility of successive developmental stages of Xenopus to probe alterations in the $\mathrm{O}_{2}$ turnover in the hindbrain during ontogeny and further elucidate the energetic demands and costs of activating basic motor behaviors. The virtual in vivo-like experimental conditions despite isolation of the tissue and loss of vascular oxygen supply allows direct probing of the $\mathrm{O}_{2}$ consumption of cell populations involved in specific behaviorally relevant neuronal computations. This includes evaluation of the influence of parameters such as temperature, ionic composition of the extracellular medium, availability, and type of metabolic substrates or the relation between $\mathrm{O}_{2}$ availability and neuronal function. Finally, isolated Xenopus preparations allow exploring the capacity of photosynthetic algae [51], experimentally introduced into the brain prior to the isolation, to produce $\mathrm{O}_{2}$ upon illumination, which thereby supplies or even enhances the $\mathrm{O}_{2}$ level in the tissue.

\section{Conclusions}

The current study reports that $\mathrm{O}_{2}$ concentrations can be reliably monitored over many hours in the ventricle of isolated amphibian brain/head preparations and that these values correlate well with $\mathrm{O}_{2}$ levels in adjacent neuronal tissue. By experimentally altering Ringer oxygenation, we directly demonstrated a saturation of the $\mathrm{O}_{2}$ consumption above $\sim 700 \mu \mathrm{mol} / \mathrm{l}$, likely due to the upper limit of $\mathrm{O}_{2}$-dependent energy production at this level. Given the in vivo-like experimental conditions, it is probable that a similar value would be obtained in the living animal. Bath application of a local anesthetic completely abolished spike activity and thereby revealed that half of the $\mathrm{O}_{2}$ consumption supplies neuronal activity. The possibility to measure at the same time $\mathrm{O}_{2}$ consumption and neuronal activity in an in vivo-like brain preparation under physiological conditions now allows to directly interfere with various aspects of the coupling between brain metabolism and neuronal computations.

\section{Methods}

\section{Animals and experimental preparation}

Xenopus laevis tadpoles of either sex $(n=81)$ at developmental stages 51-54 [52] were obtained from the inhouse animal breeding facility at the BiocenterMartinsried of the Ludwig-Maximilians-University Munich, Germany. Tadpoles were maintained in tanks with non-chlorinated water $\left(18^{\circ} \mathrm{C}\right)$ at a $12 / 12$ light/dark cycle. All experiments were performed in vitro on isolated preparations and complied with the "Principles of animal care", publication No. 86-23, revised 1985 of the National Institute of Health. Permission for these experiments was granted by the Regierung von Oberbayern (ROB-55.2-2532.Vet_03-17-24).

Tadpoles were anesthetized in $0.05 \% 3$-aminobenzoic acid ethyl ester methanesulfonate (MS-222; Pharmaq Ltd., UK) in ice-cold frog Ringer solution (in mmol/l: 75 $\mathrm{NaCl}, 25 \mathrm{NaHCO}_{3}, 2 \mathrm{CaCl}_{2}, 2 \mathrm{KCl}, 0.5 \mathrm{MgCl}_{2}, 11$ glucose, and 10 HEPES, pH 7.4) and decapitated at the level of the upper spinal cord. The skin on the dorsal part of the head was partially removed, the skull opened, the forebrain disconnected, both optic nerves severed, and the choroid plexus above the $\mathrm{IV}^{\text {th }}$ ventricle removed [31]. The remaining central nervous system, inner ears, and eyes with extraocular muscles and respective motoneuronal innervation were functionally preserved [27]. In parts of the experiments, extraocular motor spike discharge was recorded from the trochlear nerve after disconnection from the superior oblique target muscle at the innervation site. For all experiments, isolated preparations (Fig. $1 \mathrm{a}_{1}$ ) were placed in a Sylgard-lined recording chamber that was continuously superfused with Ringer solution at a constant temperature of $17.5 \pm$ $0.5^{\circ} \mathrm{C}$. The volume of the bath chamber was $\sim 2 \mathrm{ml}$ with $\sim 3 \mathrm{~mm}$ of Ringer above the dorsal surface of the isolated preparations. The $\mathrm{O}_{2}$ concentration of the Ringer under air-saturated control conditions was $\sim 290 \mu \mathrm{mol} / \mathrm{l}$ and was experimentally increased up to $\sim 1200 \mu \mathrm{mol} / \mathrm{l}$ by ventilation with carbogen $\left(95 \% \mathrm{O}_{2}, 5 \% \mathrm{CO}_{2}\right)$ in a separate chamber ( $2 \mathrm{ml}$ volume) that had a rapid outflow into the recording chamber.

\section{Oxygen measurements, electrophysiological recordings, and pharmacology}

The $\mathrm{O}_{2}$ concentration of the Ringer solution in the bath, in the $\mathrm{IV}^{\text {th }}$ ventricle, and in the brain was constantly monitored with $\mathrm{O}_{2}$ electrodes (Unisense A/S, Denmark) with tip diameters of $100 \mu \mathrm{m}$ and $10 \mu \mathrm{m}$, respectively. Electrodes were freshly calibrated prior to each experiment using solutions with $0 \mu \mathrm{mol} / \mathrm{l} \quad \mathrm{O}_{2} \quad(0.1 \mathrm{~mol} / \mathrm{l}$ 
ascorbic acid in $0.1 \mathrm{~mol} / \mathrm{l} \mathrm{NaOH}$ ), $287 \mu \mathrm{mol} / \mathrm{l} \mathrm{O}_{2}$ (air-saturated Ringer solution), and $1350 \mu \mathrm{mol} / \mathrm{l} \mathrm{O}_{2}$ (carbogensaturated Ringer solution), temperature adjusted to $17.5^{\circ} \mathrm{C}$. Profiles and gradients of the $\mathrm{O}_{2}$ concentration were acquired by dorso-ventral depth tracks in steps of $200 \mu \mathrm{m}$ at the rostro-caudal level of the VIII $^{\text {th }}$ nerve at eleven medio-lateral positions, spaced by $400 \mu \mathrm{m}$ (dots in Fig. $\left.1 a_{2}, b\right)$ and symmetrically centered on the midline of the $\mathrm{IV}^{\text {th }}$ ventricle. The $\mathrm{O}_{2}$ electrode was positioned and advanced with a piezo-stepper attached to a micromanipulator (both from Sensapex, Finland).

Spontaneous multi-unit spike discharge of the superior oblique motor nerve was recorded extracellularly (EXT 10-2F; npi electronics; Tamm, Germany) with glass suction electrodes [37]. Electrodes were pulled on a P-87 Brown/Flaming electrode puller from borosilicate glass (Science Products, Hofheim, Germany), and individually broken to fit the diameter of the superior oblique nerve. $\mathrm{O}_{2}$ concentrations and concurrent spike activity were digitized at $120 \mathrm{~Hz}$ and $5 \mathrm{kHz}$, respectively (CED 1401, Cambridge Electronic Design, UK), and stored on computer for offline analysis. The neuronal activity of the isolated preparation, detected as spontaneous multi-unit spike discharge of the superior oblique motor nerve as a proxy, was blocked by bath-application of MS-222 (0.05\%, 0.5\%). Mitochondrial activity was inhibited by bathapplication of potassium cyanide (KCN; $500 \mu \mathrm{mol} / \mathrm{l}$, Merck KGaA, Germany). For control experiments on non-living tissue, isolated preparations were fixated for $12 \mathrm{~h}$ in $70 \%$ ethanol (Merck KGaA, Germany).

\section{Data analysis}

Discharge rates of the superior oblique motor nerve were obtained from multi-unit spike activity using Spike2 (Cambridge Electronic Design, UK) scripts. Spike rates were obtained from the spike times in a given recording by counting all events above a pre-determined amplitude threshold. The threshold was set to $\sim 1.5 \times$ of the amplitude of the noise level and remained unchanged for a given experiment. The multi-unit resting discharge rate was determined as average frequency of the extracted events over a period of $\sim 2 \mathrm{~min}$. Under airsaturated $\mathrm{O}_{2}$ concentrations, this yielded values that ranged from 15 to 30 spikes/s in different preparations and complied with those reported earlier [37, 41]. The multi-unit spike events were plotted as discharge rates with a bin width of $1 \mathrm{~s}$, from which the parameters of spontaneously occurring spike bursts such as the delay with respect to of the $\mathrm{O}_{2}$ concentration or burst amplitude/integral were extracted. The burst integral was determined as area under the curve following subtraction of the resting rate from the onset of the spike burst until the time when the spike burst reached again baseline level.

The $\mathrm{O}_{2}$ concentration in the $\mathrm{IV}^{\text {th }}$ ventricle or brain and the bath chamber were measured with the technical approach and sensors described above. After each experiment, the continuously monitored bath $\mathrm{O}_{2}$ level served to estimate the oxygen consumption by calculating the difference between the measured bath $\mathrm{O}_{2}$ and the concurrent ventricular/brain $\mathrm{O}_{2}$ concentrations. The continuous monitoring of bath $\mathrm{O}_{2}$ concentrations was particularly important during experiments where the Ringer was ventilated to stepwise obtain bath $\mathrm{O}_{2}$ levels of up to $\sim 1200 \mu \mathrm{mol} / \mathrm{l}$. The integral of the $\mathrm{O}_{2}$ consumption during spike burst activity was determined as area between the baseline and the peak $\mathrm{O}_{2}$ consumption starting at the onset of the change in $\mathrm{O}_{2}$ level and the time when the $\mathrm{O}_{2}$ level reached again baseline. Integrals of spike burst-related $\mathrm{O}_{2}$ consumption at different bath $\mathrm{O}_{2}$ concentrations were determined with respect to the actual bath $\mathrm{O}_{2}$ level during a particular experimental condition.

All above-described analysis steps were performed in Spike2 and/or in Microcal Origin 6.0G (OriginLab Corp., USA) using implemented standard algorithms for the different computations such as measurements of onset latencies or response integrals. Plotting and calculation of linear regressions was performed in Microcal Origin 6.0G; respective slopes and correlation coefficients of regression lines were indicated in the text, figures, and/or figure legends. Data are presented as dot and whisker box plots and values are indicated as mean $\pm S E M$, if not stated otherwise. Statistical differences between experimental groups were calculated with the non-parametric Mann-Whitney $U$ test (unpaired parameters; Prism, Graphpad Software, Inc., USA) and indicated as $p$ values (*** $p<0.001$; $\left.{ }^{* * * *} p<0.0001\right)$ in the text.

\section{Abbreviations \\ ATP: Adenosine triphosphate; EtOH: Ethanol; FAD: Flavin adenine dinucleotide; KCN: Potassium cyanide; MS-222: Tricaine methanesulfonate; NADH: Nicotinamide adenine dinucleotide}

\section{Acknowledgements}

The authors gratefully acknowledge the technical support by the local workshop at the Faculty of Biology of the LMU.

\section{Authors' contributions}

HS and LK conceived the study. SOE acquired and analyzed the data. SOE, LK, and HS interpreted the data and wrote the manuscript. The authors read and approved the final manuscript.

\section{Funding}

Funding was provided by the German Science Foundation (CRC 870; STR 478/3-1; KU 1282/9-1), the German Federal Ministry of Education and Research under the Grant code 01 EO 0901 and the Munich Center for Neuroscience (MCN). 


\section{Availability of data and materials}

The datasets used and/or analyzed during the current study are available from the corresponding author on reasonable request.

\section{Ethics approval and consent to participate}

All experiments were approved by the Regierung von Oberbayern (ROB-55.22532.Vet_03-17-24).

\section{Consent for publication}

Not applicable.

\section{Competing interests}

The authors declare that they have no competing interests.

\section{Author details}

'Department Biology II, Ludwig-Maximilians-University Munich, Großhaderner Str. 2, 82152 Planegg, Germany. ${ }^{2}$ Graduate School of Systemic Neurosciences, Ludwig-Maximilians-University Munich, Großhaderner Str. 2, 82152 Planegg, Germany.

Received: 11 February 2020 Accepted: 16 June 2020

Published online: 03 July 2020

\section{References}

1. Bullmore $E$, Sporns $O$. The economy of brain network organization. Nat Rev Neurosci. 2012;13:336-49.

2. Attwell $D$, Laughlin SB. An energy budget for signaling in the grey matter of the brain. J Cereb Blood Flow Metab. 2001;21:1133-45.

3. Mink JW, Blumenschine RJ, Adams DB. Ratio of central nervous system to body metabolism in vertebrates: its constancy and functional basis. Am J Physiol-Regul Integr Comp Physiol. 1981;241:R203-12.

4. Ames A. CNS energy metabolism as related to function. Brain Res Rev. 2000; 34:42-68.

5. Hall CN, Klein-Flügge MC, Howarth C, Attwell D. Oxidative phosphorylation, not glycolysis, powers presynaptic and postsynaptic mechanisms underlying brain information processing. J Neurosci. 2012;32:8940-51.

6. Allaman I, Bélanger M, Magistretti PJ. Astrocyte-neuron metabolic relationships: for better and for worse. Trends Neurosci. 2011;34:76-87.

7. Dienel GA. Brain lactate metabolism: the discoveries and the controversies. J Cereb Blood Flow Metab. 2012;32:1107-38.

8. Brosel S, Grothe B, Kunz L. An auditory brainstem nucleus as a model system for neuronal metabolic demands. Eur J Neurosci. 2018;47:222-35.

9. Huchzermeyer C, Albus K, Gabriel H-J, Otáhal J, Taubenberger N, Heinemann U, et al. Gamma oscillations and spontaneous network activity in the hippocampus are highly sensitive to decreases in pO2 and concomitant changes in mitochondrial redox state. J Neurosci. 2008;28:1153-62.

10. Schneider J, Berndt N, Papageorgiou IE, Maurer J, Bulik S, Both M, et al. Local oxygen homeostasis during various neuronal network activity states in the mouse hippocampus. J Cereb Blood Flow Metab. 2019;39:859-73.

11. Galeffi F, Somjen GG, Foster KA, Turner DA. Simultaneous monitoring of tissue $\mathrm{pO} 2$ and $\mathrm{NADH}$ fluorescence during synaptic stimulation and spreading depression reveals a transient dissociation between oxygen utilization and mitochondrial redox state in rat hippocampal slices. J Cereb Blood Flow Metab. 2011;31:626-39.

12. Ivanov A, Zilberter Y. Critical state of energy metabolism in brain slices: the principal role of oxygen delivery and energy substrates in shaping neuronal activity. Front Neuroenerg. 2011;3. https://doi.org/10.3389/fnene.2011.00009.

13. Sengupta B, Stemmler M, Laughlin SB, Niven JE. Action potential energy efficiency varies among neuron types in vertebrates and invertebrates. PLOS Comput Biol. 2010;6:e1000840.

14. Hallermann S, de Kock CPJ, Stuart GJ, Kole MHP. State and location dependence of action potential metabolic cost in cortical pyramidal neurons. Nat Neurosci. 2012;15:1007-14.

15. Shuttleworth $\mathrm{CW}$. Use of $\mathrm{NAD}(\mathrm{P}) \mathrm{H}$ and flavoprotein autofluorescence transients to probe neuron and astrocyte responses to synaptic activation. Neurochem Int. 2010;56:379-86.

16. Lipton P. Effects of membrane depolarization on nicotinamide nucleotide fluorescence in brain slices. Biochem J. 1973;136:999-1009.
17. Husson TR, Mallik AK, Zhang JX, Issa NP. Functional imaging of primary visual cortex using flavoprotein autofluorescence. J Neurosci. 2007;27: 8665-75.

18. Gordon GRJ, Choi HB, Rungta RL, Ellis-Davies GCR, MacVicar BA. Brain metabolism dictates the polarity of astrocyte control over arterioles. Nature. 2008:456:745-9.

19. Reinert KC, Gao W, Chen G, Wang X, Peng Y-P, Ebner TJ. Cellular and metabolic origins of flavoprotein autofluorescence in the cerebellar cortex in vivo. Cerebellum. 2011;10:585.

20. Kann O, Hollnagel J-O, Elzoheiry S, Schneider J. Energy and potassium ion homeostasis during gamma oscillations. Front Mol Neurosci. 2016;9. https:// doi.org/10.3389/fnmol.2016.00047.

21. Mächler P, Wyss MT, Elsayed M, Stobart J, Gutierrez R, von Faber-Castell A, et al. In vivo evidence for a lactate gradient from astrocytes to neurons. Cell Metab. 2016;23:94-102.

22. Nawroth JC, Greer CA, Chen WR, Laughlin SB, Shepherd GM. An energy budget for the olfactory glomerulus. J Neurosci. 2007;27:9790-800.

23. Howarth C, Gleeson P, Attwell D. Updated energy budgets for neural computation in the neocortex and cerebellum. J Cereb Blood Flow Metab. 2012;32:1222-32.

24. Trattner B, Gravot CM, Grothe B, Kunz L. Metabolic maturation of auditory neurones in the superior olivary complex. PLoS One. 2013;8:e67351.

25. Moujahid A, D'Anjou A, Graña M. Energy demands of diverse spiking cells from the neocortex, hippocampus, and thalamus. Front Comput Neurosci. 2014;8:41.

26. Huchzermeyer C, Berndt N, Holzhütter H-G, Kann O. Oxygen consumption rates during three different neuronal activity states in the hippocampal CA3 network. J Cereb Blood Flow Metab. 2013;33:263-71.

27. Straka H, Simmers J. Xenopus laevis: an ideal experimental model for studying the developmental dynamics of neural network assembly and sensory-motor computations. Dev Neurobiol. 2012;72:649-63.

28. Direnberger S, Banchi R, Brosel S, Seebacher C, Laimgruber S, Uhl R, et al. Analysis of signal processing in vestibular circuits with a novel lightemitting diodes-based fluorescence microscope. Eur J Neurosci. 2015;41: 1332-44.

29. Bothe MS, Luksch $H$, Straka $H$, Kohl T. Neuronal substrates for infrared contrast enhancement and motion detection in rattlesnakes. Curr Biol. 2019; 29:1827-32 e4.

30. Rosenberg AF, Ariel M. Visual-response properties of neurons in turtle basal optic nucleus in vitro. J Neurophysiol. 1990;63:1033-45.

31. Dietrich $\mathrm{H}$, Glasauer S, Straka H. Functional organization of vestibulo-ocular responses in abducens motoneurons. J Neurosci. 2017;37:4032-45.

32. Chagnaud BP, Banchi R, Simmers J, Straka H. Spinal corollary discharge modulates motion sensing during vertebrate locomotion. Nat Commun. 2015:6:1-14.

33. Özugur S, Kunz L, Straka H. Semi-intact preparations of larval amphibians for studying oxygen consumption and energy metabolism in the brain. Soc Neurosci Abstr. 2018;44:253.04.

34. Pettersen JC, Cohen SD. The effects of cyanide on brain mitochondrial cytochrome oxidase and respiratory activities. J Appl Toxicol. 1993;13:9-14.

35. Bai C-X, Glaaser IW, Sawanobori T, Sunami A. Involvement of local anesthetic binding sites on IVS6 of sodium channels in fast and slow inactivation. Neurosci Lett. 2003;337:41-5.

36. Ramlochansingh C, Branoner F, Chagnaud BP, Straka H. Efficacy of tricaine methanesulfonate (MS-222) as an anesthetic agent for blocking sensory-motor responses in Xenopus laevis tadpoles. PLoS One. 2014;9: e101606.

37. Soupiadou P, Branoner F, Straka H. Pharmacological profile of vestibular inhibitory inputs to superior oblique motoneurons. J Neurol. 2018;265:18-25.

38. Branoner F, Straka H. Semicircular canal influences on the developmental tuning of the translational vestibulo-ocular reflex. Front Neurol. 2018;9:404.

39. Straka H, Baker R, Gilland E. Rhombomeric organization of vestibular pathways in larval frogs. J Comp Neurol. 2001;437:42-55.

40. Scholz A. Mechanisms of (local) anaesthetics on voltage-gated sodium and other ion channels. Br J Anaesth. 2002;89:52-61.

41. I Gusti Bagus M, Gordy C, Sanchez-Gonzalez R, Strupp M, Straka H. Impact of 4-aminopyridine on vestibulo-ocular reflex performance. J Neurol. 2019;266:93-100.

42. Lambert FM, Combes D, Simmers J, Straka H. Gaze stabilization by efference copy signaling without sensory feedback during vertebrate locomotion. Curr Biol. 2012;22:1649-58. 
43. Turner DA, Foster KA, Galeffi F, Somjen GG. Differences in O2 availability resolve the apparent discrepancies in metabolic intrinsic optical signals in vivo and in vitro. Trends Neurosci. 2007;30:390-8.

44. Lyons DG, Parpaleix A, Roche M, Charpak S. Mapping oxygen concentration in the awake mouse brain. elife. 2016;5:e12024.

45. Ndubuizu O, LaManna JC. Brain tissue oxygen concentration measurements. Antioxid Redox Signal. 2007;9:1207-20.

46. Erecińska M, Silver IA. Tissue oxygen tension and brain sensitivity to hypoxia. Respir Physiol. 2001;128:263-76.

47. Engl E, Attwell D. Non-signalling energy use in the brain. J Physiol. 2016: 3417-29.

48. Engl E, Jolivet R, Hall CN, Attwell D. Non-signalling energy use in the developing rat brain. J Cereb Blood Flow Metab. 2017:37:951-66.

49. Attili S, Hughes SM. Anaesthetic tricaine acts preferentially on neural voltage-gated sodium channels and fails to block directly evoked muscle contraction. PLoS One. 2014;9:e103751.

50. Hyder F, Rothman DL, Bennett MR. Cortical energy demands of signaling and nonsignaling components in brain are conserved across mammalian species and activity levels. Proc Natl Acad Sci. 2013;1 10:3549-54

51. Schenck TL, Hopfner U, Chávez MN, Machens H-G, Somlai-Schweiger I, Giunta RE, et al. Photosynthetic biomaterials: a pathway towards autotrophic tissue engineering. Acta Biomater. 2015;15:39-47.

52. Nieuwkoop PD, Faber J. Normal table of Xenopus laevis (daudin): a systematical and chronological survey of the development from the fertilized egg till the end of metamorphosis. Garland Pub.; 1994.

\section{Publisher's Note}

Springer Nature remains neutral with regard to jurisdictional claims in published maps and institutional affiliations.

Ready to submit your research? Choose BMC and benefit from:

- fast, convenient online submission

- thorough peer review by experienced researchers in your field

- rapid publication on acceptance

- support for research data, including large and complex data types

- gold Open Access which fosters wider collaboration and increased citations

- maximum visibility for your research: over $100 \mathrm{M}$ website views per year

At $\mathrm{BMC}$, research is always in progress.

Learn more biomedcentral.com/submissions 